Article

\title{
Evaluation of Press Mud, Vinasse Powder and Extraction Sludge with Ethanol in a Pyrolysis Process
}

\author{
John Steven Devia-Orjuela ${ }^{1}$, Christian E Alvarez-Pugliese ${ }^{1, *} \mathbb{C}$, Dayana Donneys-Victoria ${ }^{1}(\mathbb{D}$,

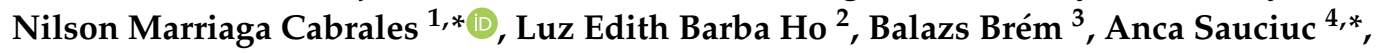 \\ Emese Gál ${ }^{3,5}$, Douglas Espin ${ }^{6}$, Martin Schichtel ${ }^{7}$, Dimitrina Lang ${ }^{7}$, Sebastiano Giardinelli ${ }^{8}$ \\ and Maria Briceno ${ }^{9}$ \\ 1 Department of Chemical Engineering, Universidad del Valle, Calle 13 \# 100-00, Cali 76001, Colombia; \\ steven.devia.o@correounivalle.edu.co (J.S.D.-O.); dayana.donneys@correounivalle.edu.co (D.D.-V.) \\ 2 Department of Sanitary and Environmental Engineering, Universidad del Valle, Calle 13 \# 100-00, Cali 76001, \\ Colombia; luz.barba@correounivalle.edu.co \\ 3 Department of Chemistry and Chemical Engineering, Hungarian Line of Study, Babeş-Bolyai University, \\ 11 Arany János St., 400028 Cluj-Napoca, Romania; bbrem@chem.ubbcluj.ro (B.B.); \\ emese@chem.ubbcluj.ro (E.G.) \\ 4 ROCAT Synfuels, 22 Valea-Cetatii, 500289 Brasov, Romania \\ 5 Institute of Research-Development-Innovation in Applied Natural Sciences, Babes-Bolyai University, \\ Fantanele 30, 400294 Cluj-Napoca, Romania \\ 6 Neotechnology, Science Park 2, 66123 Saarbrucken, Germany; despin@neotechnology.us \\ 7 Kraftblock (Nebuma), Campus Geb. A1, 66123 Saarbrücken, Germany; mas@nebuma.com (M.S.); \\ dimitrina@kraftblock.com (D.L.) \\ 8 Ecotek, City of Knowledge, building 239, Clayton 0843-03081, Panama; sgiardinella@ecotekgrp.com \\ 9 Ambitek Services Inc., City of Knowledge, building 231, Clayton 0843-03081, Panama; \\ mbriceno@ambitek.com.pa \\ * Correspondence: christian.alvarez@correounivalle.edu.co (C.E.A.-P.); \\ nilson.marriaga@correounivalle.edu.co (N.M.C.); anca.sauciuc@rocatsynfuels.com (A.S.)
}

Received: 27 August 2019; Accepted: 17 September 2019; Published: 30 October 2019

\begin{abstract}
The effluents of the sugar and bio-ethanol industry, mainly vinasse as well as lignocellulosic waste, are produced in high volumes. Therefore, their treatment and valorization would reduce the environmental impact and make this industry more productive and competitive. The purpose of this study was to determine the potential use of press mud (lignocellulosic waste), vinasse powder, and vinasse sludge from an extraction process with ethanol, as raw materials for conventional pyrolysis evaluating the physicochemical characteristics that affect this thermochemical process, such as calorific power, density, ash content, volatile material, moisture and nitrogen, sulfur, carbon and hydrogen content, thermogravimetric profile, and quantification of lignin cellulose and hemicellulose. The batch pyrolysis experiments showed that all three wastes could be converted successfully into more valuable products. The powder vinasse led to the formation of the lowest content of bio-char $(42.7 \%)$, the highest production of volatiles (61.6 wt.\%), and the lowest ash content (20.5 wt.\%). Besides, it showed the high heating value of $15.63 \mathrm{MJ} / \mathrm{kg}$. Meanwhile, the extraction sludge presented the highest liquid yield (32\%) with the lowest gas formation (18.2 wt.\%) and the lowest heating value of $8.57 \mathrm{MJ} / \mathrm{kg}$. Thus, the sludge could be a good feedstock for production of bio-oil and bio-char.
\end{abstract}

Keywords: lignocellulosic waste; pyrolysis; biowaste; sugar cane

\section{Introduction}

According to the most recent report of the United States Department of Agriculture (USDA), the world's sugar production was 178.926 million metric tons for the marketing year 2018/19, with a 
stable trend for the past four years [1]. Colombia is within the first 20 countries in the world in terms of sugar production, with 2.4 million tons in the 2018/19 year (Figure 1) [1] and with a well-developed industry that takes advantage of having the world highest productivity, approximately 16.2 tons of sugar per hectare per year [2]. The sugarcane industry is concentrated in the south-western region of the country, specifically in the geographic valley of the Cauca river, with a planted area of 243,232 hectares and 13 industrial sugar mills that generate 286,000 direct and indirect jobs [2].

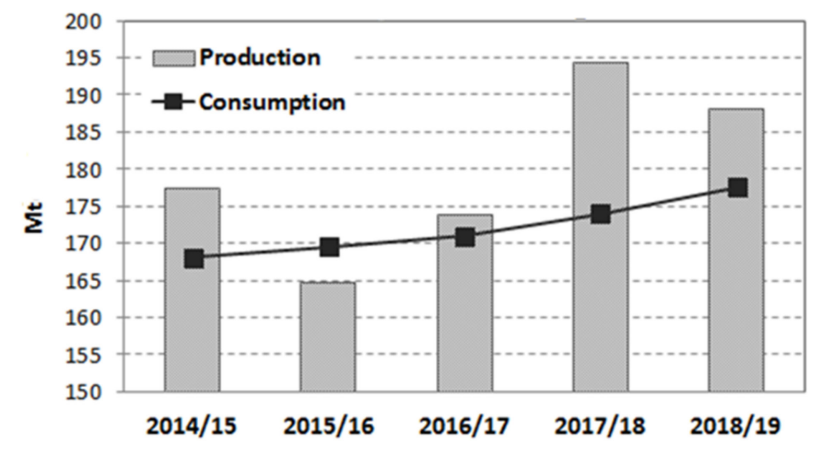

(a)

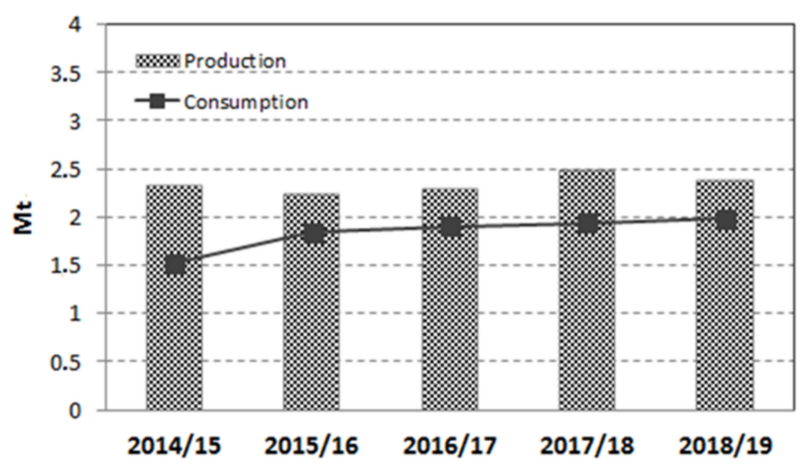

(b)

Figure 1. Sugar production and consumption worldwide (a) and in Colombia (b) [1].

The productive process of the sugar industry is intensive in the generation of solid and liquid sub-streams. The major solid wastes generated are bagasse and press mud. The bagasse, which is the residue that remains after the sugarcane milling, is produced in a proportion of $0.30-0.34$ tons per 1 ton of sugar cane processed [3] and has a high content of cellulose $(23 \%-45 \%)$, hemicellulose $(12 \%-28 \%)$, and lignin $(10 \%-20 \%)$ [3,4]. It is also composed of sugar (5\%) and minerals (1\%) [3]. Owing to its calorific power, bagasse is mostly used in energy cogeneration in the sugar mills, although a broad range of uses has been proposed for this material; however, most of them have not been commercially exploited [5]. One particular company in Colombia uses $15 \%$ of the bagasse to produce paper without mixing with other types of vegetable fibers. The remaining $85 \%$ is used in energy cogeneration in the sugar mills [6].

The press mud or filter cake, which is the waste obtained from the clarification and filtration processes of the sugar juice, is produced in a range of 0.01 to 0.07 tons per ton of ground sugarcane [4]. The composition of the press mud is very variable; however, it is characterized by a high content of proteins, sugar, and fiber. In fact, the press mud in Colombia is used in a composting process to produce fertilizers. In recent years, there have been studies reporting different uses for valorization of these solid wastes beyond the agronomic use [5], either as a source of renewable energy (biogas production) [7] or products of greater added value in areas like the pharmaceutical and food industries [3,4]. 
In addition, the vinasse produced in the distillation towers is the main liquid effluent of the bio-ethanol sub-process from sugarcane [8]. It presents a dark brown color and generates ethanol in a 10 to 1 volumetric ratio (vinasse/ethanol). It is characterized by low $\mathrm{pH}$ values, high chemical oxygen demand (COD: 32,000-109,700 mg/L), and biological oxygen demand (BOD ${ }_{5}$ : $13,414-87,700 \mathrm{mg} / \mathrm{L}$ ) [9,10]. Vinasse is composed mainly of water; organic solids; and minerals like potassium, calcium, and magnesium [10]. At present, there are different ways for the treatment or disposal of the vinasse such as composting, concentration by evaporation, and fertigation, among others. Concentration by evaporation (concentrating vinasse from $5 \%$ in solids to $20 \%-50 \%$ ) and composting are the most viable options applied in Colombia. In composting, the organic substrate is degraded, and the water evaporated, resulting in a stable solid product that is rich in nutrients for the soil; however, this process has low added value, and requires a long residence time (more than 40 days) and large land areas-the high volumes of lignocellulosic material (crop residues and press mud) require to be mixed with vinasse in a proportion of $80 \%-90 \%$ solid waste to $10 \%-20 \%$ vinasse to achieve the desired product [11]. Meanwhile, fertigation, which is the direct disposal of vinasse into soils widely used in Brazil, has the purpose of recovering nutrients (mainly the potassium) and reusing the water to meet the nutritional requirements of sugarcane [12]. However, it has raised concerns regarding the ability of the soils to assimilate the high dosages $\left(100-150 \mathrm{~m}^{3} / \mathrm{ha}\right.$ ) that may result in the unbalance of soil nutrients and groundwater contamination [11]. In fact, vinasse management is still an unsolved problem for many sugar mills, and researchers suggest that new studies on green methods need to be developed aiming at the recycling and disposal of sugarcane vinasse [11].

An alternative for the sugarcane industry wastes' valorization is the pyrolysis process, which can convert the residues into high added-value products. The process consists of the thermal decomposition of materials in the absence of oxygen. The advantages of biomass pyrolysis are the production of both valuable liquid and solid products, as well as a non-condensable gas fraction. The liquid fraction, bio-oil, can be used in combustion engines and gas turbines [13]. Moreover, the liquid pyrolysis fraction can be used for production of various speciality chemicals [14,15]. Bio-char, the solid fraction, has several applications as a fuel (substitute for coke), activated carbon (adsorbent), or fertilizer for soils (hosting microbes, slowly releasing nutrients and water) [14]. The variables of biomass pyrolysis to achieve desired relative amounts of fractions in the pyrolysis process have been intensively studied, including the type of pyrolysis applied (slow, moderate, fast), reactor design, influence of biomass composition, moisture, size, and operating conditions (temperature, heating rate, gas flow, catalyst type, and loading) $[15,16]$.

Previous studies have shown the feasibility of using pyrolysis for sugarcane bagasse, demonstrating that the bio-oil can be potentially valuable as a renewable fuel and can be used as a chemical feedstock [17,18], while the bio-char can be used as a solid fuel, a cheap adsorbent, feedstock for activated carbon production, and in agricultural applications [19-22]. However, studies for press mud $[23,24]$ and vinasse $[25,26]$ pyrolysis are scarce. One of the reasons is because of the additional energy needed to dry both wastes, especially the vinasse, as samples prior to pyrolysis should be dried to a low moisture content to minimize the water content in the resulting bio-oil.

The high organic content in dried vinasse as well as in press mud, and their high availability (only in Colombia, the annual press mud and concentrated vinasse- $40 \%$ to $55 \%$ solids-production can be estimated in 1.4 million tons and 2.7 million tons per year, respectively $[2,5,27,28])$ suggest an interesting opportunity for these biomass wastes to be used as feedstock in a thermochemical valorization process. Therefore, the objective of this work is to describe a non-catalysed slow pyrolysis study using a batch reactor unit and three biomass waste samples produced in an industrial sugar and bio-ethanol plant. The biomass samples were characterized prior to pyrolysis tests, and the effect of biomass type on the yield and chemical composition of bio-oil and bio-char was investigated. 


\section{Materials and Methods}

\subsection{Raw Material}

The press mud (Figure 2a) was obtained from the clarification and filtration stage of a commercial sugar mill located at the Cauca River valley (Colombia). The sample had an initial humidity of $62.8 \%$. Preconditioning of the press mud was carried out according to ASTM E 871 standard-drying the sample at $105^{\circ} \mathrm{C}$ for one hour. Milling and sieving were carried out to obtain a press mud sample with a particle size smaller than $0.5 \mathrm{~mm}$.
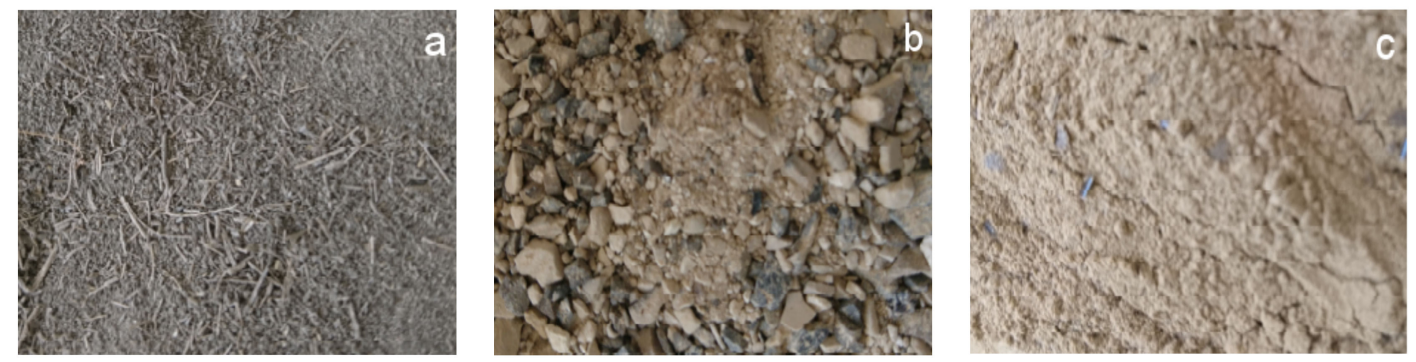

Figure 2. Biomass waste samples from bioethanol processes. (a) Press mud; (b) powder vinasses; (c) extraction sludge.

Two different solid vinasse samples were studied. The first one was an extraction sludge (Figure 2b) from a protein denaturation process described by Yadav and Chandra [29], in which ethanol and vinasse are mixed in a $500 \mathrm{~mL}$ separating funnel in equal volumetric proportions [30]. The mixture was stirred, and the solids were allowed to settle for two hours. Subsequently, the supernatant was filtered with a qualitative filter, the sludge was dried at room temperature for two hours, and the ethanol in the supernatant was separated by distillation.

The second sample was a powdered vinasse (Figure 2c) supplied by Biogreen Corporación S.A.S with a humidity of $5.6 \%$ and a maximum particle size of 80 mesh. The sample was obtained by drying the concentred vinasse (50\% in solids) by means of a patented industrial process [31].

Figure 3 shows the sugar and bio-ethanol process block diagram, including the vinasse powder and the vinasse sludge production sections. 


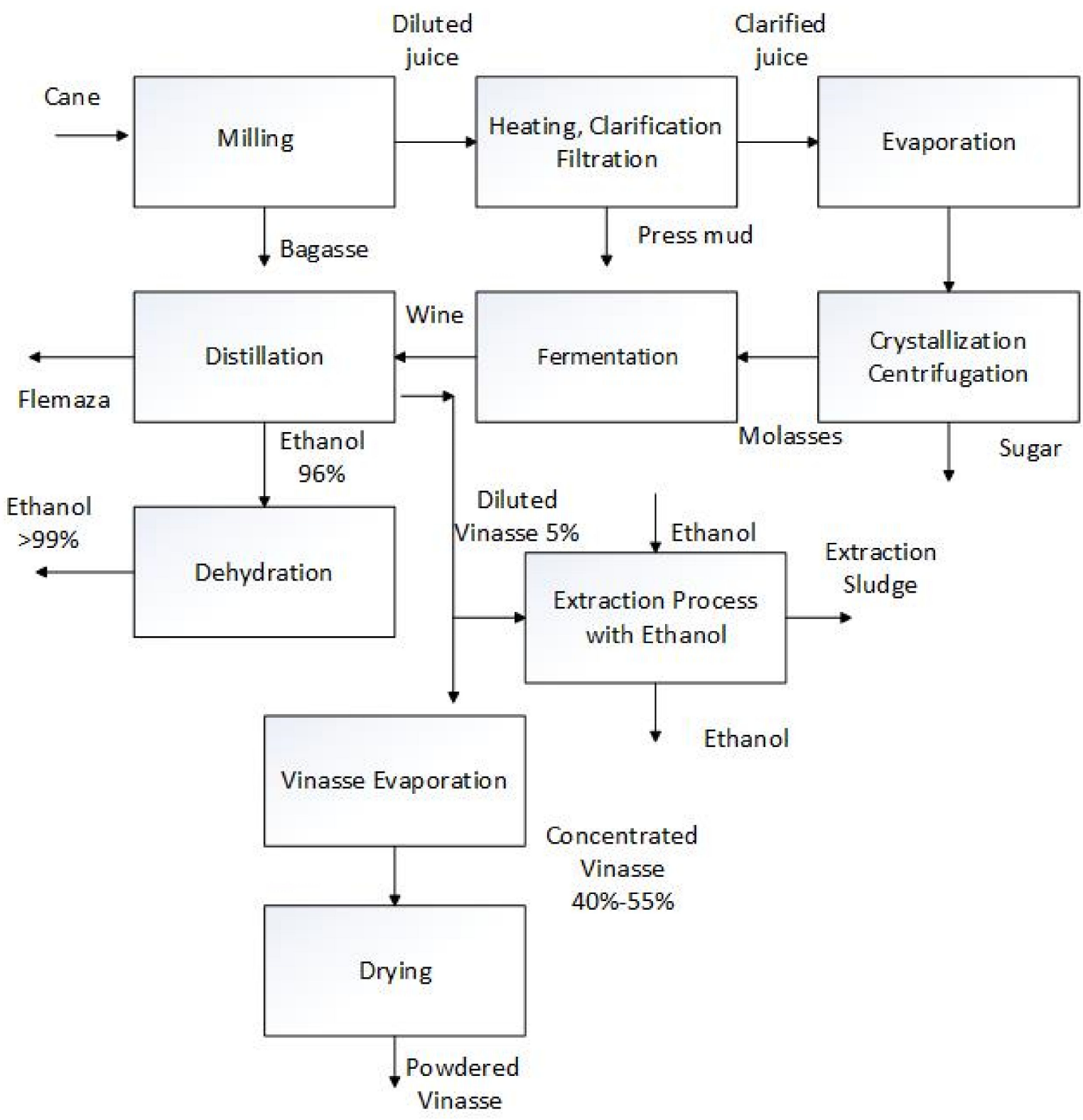

Figure 3. Sugar and bioethanol process block diagram.

\subsection{Pyrolysis Tests}

All pyrolysis tests were carried out in a batch scale reactor unit. The laboratory-scale pyrolysis unit (Figure 4) consists of a stainless steel reactor with $50 \mathrm{~mm}$ internal diameter and $300 \mathrm{~mm}$ length, a cooling unit formed by four condensers, and a gas scrubber to retain any other volatile organic compounds that did not condense in the cooling system. While the first two condensers are at room temperature (first condenser to retain any biomass particles that might be driven by gas flow, second condenser to trap the heaviest fraction), the third condenser is cooled with ice, and the fourth condenser is cooled with liquid nitrogen. The reactor is heated inside an electrical furnace fitted with a thermocouple and a temperature controller. For all experiments, $50 \mathrm{~g}$ of each biomass sample was loaded directly in the reactor. The loaded reactor was sealed and placed inside the electrical furnace. The reactor was externally heated from room temperature to $450{ }^{\circ} \mathrm{C}$ at a heating rate of $7-8{ }^{\circ} \mathrm{C} / \mathrm{min}$. When the temperature reached $100{ }^{\circ} \mathrm{C}$, nitrogen flowing at a rate of $50 \mathrm{~L} / \mathrm{h}$ was injected through the reactor. The pyrolysis tests were performed at $450{ }^{\circ} \mathrm{C}$ for $2 \mathrm{~h}$ to ensure maximum conversion of biomass waste particles. Afterward, the reactor was cooled down to $100^{\circ} \mathrm{C}$ under a nitrogen flow of $50 \mathrm{~L} / \mathrm{h}$ and then it was allowed to reach room temperature overnight. During pyrolysis and cooling of the reactor, 
the liquid fraction was collected in condensers. After cooling, the reactor was removed from the electrical furnace.

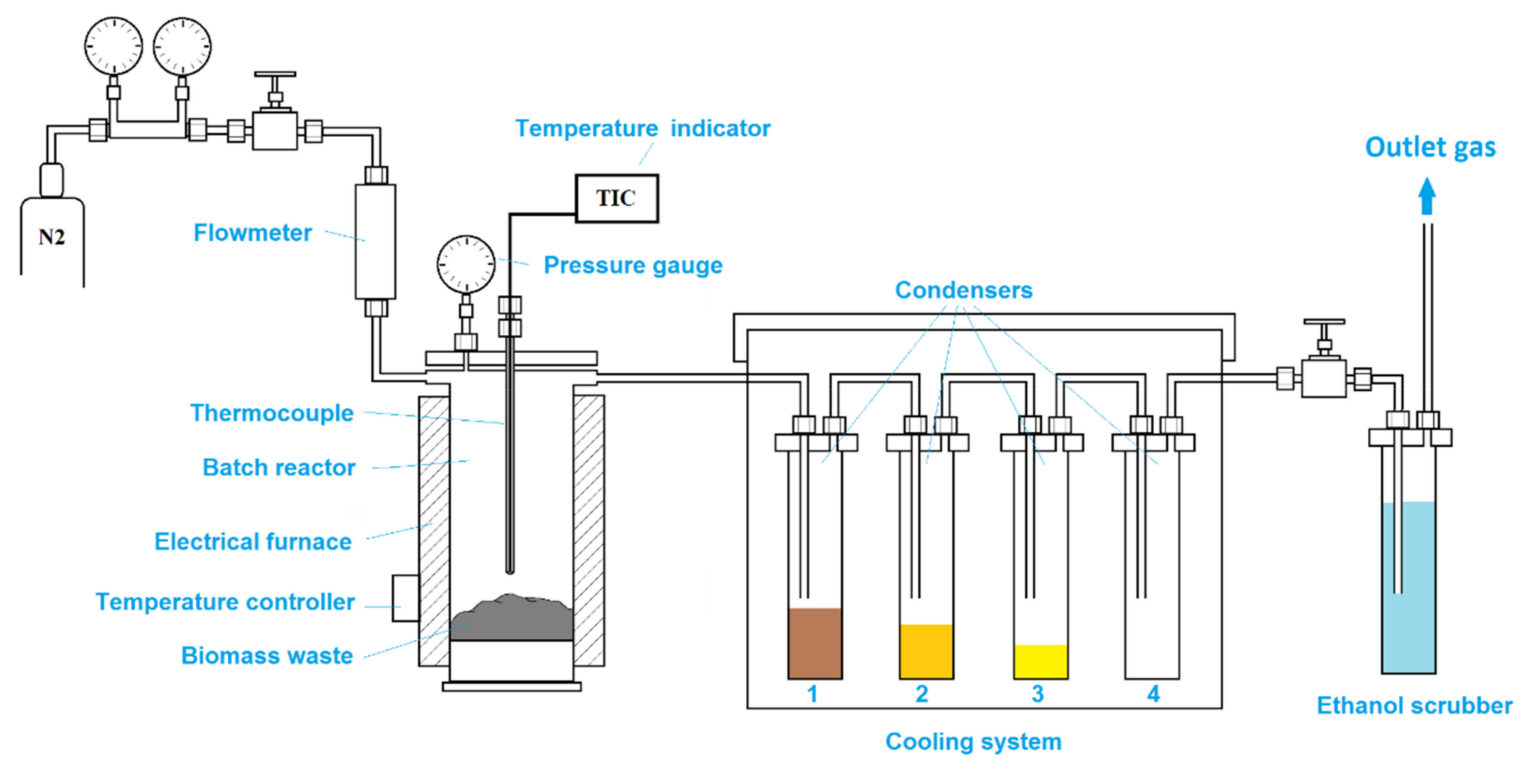

Figure 4. Schematic diagram of the slow pyrolysis unit.

The amount of bio-char and condensed liquid from each condenser was measured, and the liquid products were afterwards recovered from each condenser with ethanol $95 \%$ and acetone $98 \%$. The measure of bio-char and condensed liquid allowed the computation of the material balance.

\subsection{Analysis}

The proximate and elementary analyses on biomass samples were carried out in accordance with the following standards: ASTM D 3302 for moisture, ASTM D 3175 for volatile material, ASTM D 5865 for high heating value, ASTM D 3174 for ash content, ASTM D 3172 for fixed carbon content, ASTM D 4239 for sulfur content, ASTM D 5373 for nitrogen and oxygen content, and ASTM D 5865 for low heating value. The cellulose and hemicellulose content was obtained according to the SCAM-CM 71:09 procedure by hydrolysis with $\mathrm{H}_{2} \mathrm{SO}_{4}$, followed by the measurement of carbohydrates through high performance liquid chromatography (HPLC) system equipped with refractive index detector and the following columns: Shodex sugar SP0810 or Biorad Aminex HPX-87P column (or equivalent) with ionic form $\mathrm{H}^{+} / \mathrm{CO}_{3}$ deashing guard column and Biorad Aminex HPX-87H column (or equivalent) with corresponding guard column. The lignin content was determined by extraction of the solid samples with ethanol according to TAPPI 204 standard and then subjecting the sample free of extractive components, according to the TAPPI 222 standard, to two acid hydrolysis to finally dry, weigh, and measure the lignin using a UV spectrophotometer [32].

The thermogravimetric (TGA) analysis was performed with an STD Q 600 equipment using $10 \mathrm{mg}$ of samples heated in a nitrogen atmosphere up to $1000{ }^{\circ} \mathrm{C}$, at a heating rate of $20^{\circ} \mathrm{C} \mathrm{min}{ }^{-1}$.

For the pyrolysis tests, the moisture content of bio-char was determined by the oven drying method, according to ASTM D 4442-07.

The FT-IR spectra were used to obtain the chemical structure of the waste biomass samples utilized in the pyrolysis tests, as well as their corresponding bio-char. The samples were analysed in a Bruker Vector 22 spectrometer at $4 \mathrm{~cm}^{-1}$ resolution using the $\mathrm{KBr}$ pellet method at room temperature; 20 scans were single-averaged in the $4000-600 \mathrm{~cm}^{-1}$ region. Baseline and smooth corrections of the spectra were performed for each analysis.

The chemical composition of pyrolysis bio-oils was determined using a GC-2010 Shimadzu gas chromatograph connected to GCMS-QP2010 Plus mass spectrometer (MS). A capillary column HP-1 
(100\% dimethylpolysiloxane) of $25 \mathrm{~m}$ with $0.2 \mathrm{~mm}$ ID and thickness of $0.33 \mu \mathrm{m}$ was used for all the analyses. The temperature program started heating up to $40{ }^{\circ} \mathrm{C}$ for $5 \mathrm{~min}$; then, the temperature was increased from $40{ }^{\circ} \mathrm{C}$ to $300^{\circ} \mathrm{C}$ with a ramp of $5^{\circ} \mathrm{C} \mathrm{min}^{-1}$. The injection temperature was set at $250{ }^{\circ} \mathrm{C}$. The MS was operated in the electron ionization mode within the $35-650 \mathrm{~m} / \mathrm{z}$ range. The ion source temperature was set to $220^{\circ} \mathrm{C}$, and the interface temperature to $250{ }^{\circ} \mathrm{C}$.

\section{Results and Discussion}

\subsection{Analysis of Raw Materials}

Table 1 shows the proximate and elementary analysis of the press mud, the extraction sludge, and the vinasse powder samples.

Table 1. Proximate and elementary analysis.

\begin{tabular}{ccccc}
\hline Analysis & Method & Press Mud & Vinasse Powder & Extraction Sludge \\
\hline Moisture (\% wt) & ASTM D 3302 & 2.06 & 5.60 & 7.53 \\
Volatile material (\% wt) & ASTM D 3175 & 40.67 & 61.66 & 47.79 \\
High heating value & ASTM D 5865 & 8.57 & 15.63 & 9.27 \\
(MJ/kg) & & & & 3991 \\
High heating value & ASTM D 5865 & 3686 & 6721 & 40.13 \\
(BTU/lb) & ASTM D 3174 & 53.83 & 20.56 & 4.55 \\
Ash (\% wt) & ASTM D 3172 & 3.45 & 12.18 & 0.85 \\
Fixed Carbon (\% wt) & ASTM D 4239 & 0.13 & 1.47 & 2.73 \\
Sulfur (\% wt) & ASTM D 5373 & 0.81 & 1.84 & 3.97 \\
Nitrogen (\% wt) & ASTM D 5373 & 21.50 & 34.99 & 21.91 \\
Carbon (\% wt) & ASTM D 5373 & 3.33 & 4.75 & 3545 \\
Hydrogen (\% wt) & ASTM D 5373 & 18.34 & 30.78 & 6212 \\
Oxygen (\% wt) & ASTM D 5865 & 3349 & & \\
Low heating value & & &
\end{tabular}

The high heating value (HHV) of the press mud was $8.57 \mathrm{MJ} / \mathrm{kg}$, which is lower than values previously reported in the literature (17.0 MJ/kg [7], $12.5 \mathrm{MJ} / \mathrm{kg}$ [24]). This may be because of the widely variable composition of press muds. In previous studies, lower ash contents were reported, likely owing to different technologies used in the industrial filtration stage [33]. Similarly, the extraction sludge also has a relatively low HHV of $9.27 \mathrm{MJ} / \mathrm{kg}$, probably owing to its moisture $(7.53 \%)$ and rather high ash content $(40.13 \%)$.

Vinasse powder has the highest HHV, which is similar to reported values for bagasse (18.9 MJ/kg [24]) and other lignocellulosic wastes like rice husk (14.09 MJ/kg) and palm kernel shell (18.96 MJ/kg) [28]. In addition, the vinasse powder has the highest proportion of volatile material, implying higher yields of light bio-oil fractions and gas [28]. As mentioned before, the press mud and the extraction sludge present the highest ash content, which adversely affects the high heating value, while the vinasse powder has an ash content of $20.56 \%$, which is in the range of feedstock material for pyrolysis and gasification processes [24]. This is an indication that powder vinasse has a promising potential as feedstock for pyrolysis.

The results of the fixed carbon, oxygen, and carbon are also higher for the powder vinasse with respect to those of the press mud and those of the extraction sludge, which indicates better yields of the powder vinasse either to form bio-char or solid fuels. The high content of oxygen and carbon suggests the presence of organic groups characteristic of lignocellulosic materials [22]. On the other hand, the sulfur and nitrogen values of both press mud and powder vinasse are low, being consistent with values reported in the literature [34,35].

It can be seen in Table 2 that the lignin content for press mud, powder vinasse, and extraction sludge is high in proportion to the cellulose and hemicellulose, while bagasse is high in cellulose and 
hemicellulose [28]. A higher lignin content relates to the formation of increased bio-char yield during pyrolysis. It is also expected that the press mud and the powder vinasse, in particular, degrade at higher temperatures owing to the high content of lignin, which decomposes in a temperature range of $395-500{ }^{\circ} \mathrm{C}[7]$.

Table 2. Composition of cellulose, hemicellulose, and lignin of waste biomass feedstock.

\begin{tabular}{cccc}
\hline Component & Press Mud & Powder Vinasse & Extraction Sludge \\
\hline Lignin (\%) & 17.4 & 23.0 & 12.9 \\
Cellulose (\%) & 12.8 & 12.7 & 7.5 \\
Hemicellulose (\%) & 6.5 & 8.7 & 5.0 \\
\hline
\end{tabular}

The thermal behavior of the press mud is shown in Figure 5, which shows the mass loss (TGA) and derivative mass loss (DTA) profiles as a function of temperature, within the temperature range of $25-1000^{\circ} \mathrm{C}$. From this figure, the mass loss of press mud can be divided into four phases: the first phase, $25^{\circ} \mathrm{C}$ to $150^{\circ} \mathrm{C}$, was attributed to the elimination of the free and bound moisture present in the material [24]. Then, during the second step, a significant loss of the mass $(\sim 32 \%)$ was observed ranging from $150{ }^{\circ} \mathrm{C}$ to $350^{\circ} \mathrm{C}$. In this range, the derivative thermogravimetry (DTG) curve shows a peak at $310^{\circ} \mathrm{C}$. This behavior is the result of the decomposition of hemicellulose and cellulose [26]. Afterward, lignin decomposition occurred in the $350-470{ }^{\circ} \mathrm{C}$ range with a mass loss of $\sim 13 \%$. In the last phase, the slope presented small variations corresponding to the degradation of oxygenated compounds that are stable at a high temperature. The residue of the sample is left as char.

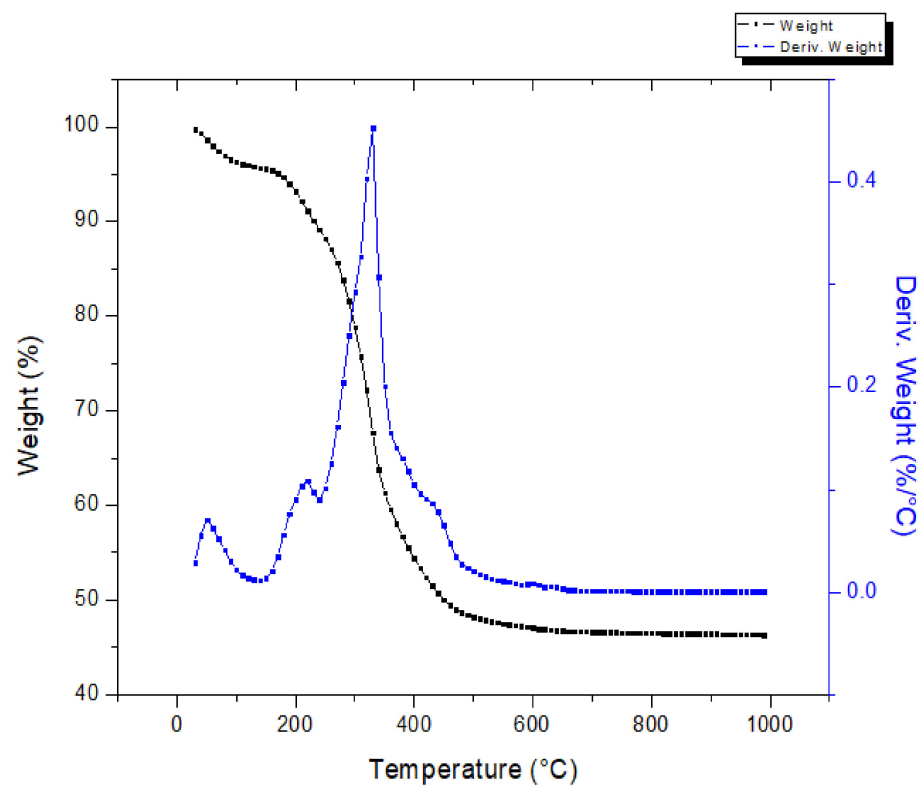

Figure 5. Thermogravimetric analysis of press mud.

The thermogravimetric analysis of vinasse powder is presented in Figure 6. The overall mass loss of vinasse can be divided into five phases. The first phase corresponds to the removal of free moisture, bond moisture, and evaporation of volatile matter in the range of $25-100{ }^{\circ} \mathrm{C}$ and $100-200{ }^{\circ} \mathrm{C}$, respectively. In the second phase, there occurs the main volatilization, and a mass loss of $\sim 30 \%$ is achieved. Then, a mass loss of $\sim 5 \%$, followed by a weight loss of $30 \%$ with a decomposition peak temperature at $475^{\circ} \mathrm{C}$, can be seen in the range of $400-475^{\circ} \mathrm{C}$. Finally, no mass loss was detected up to $1000^{\circ} \mathrm{C}$. Vinasse decomposed at higher temperature than the press mud.

Figure 7 shows the TGA-DTG curves for the extraction sludge. The thermal behavior of the sludge presented seven phases. Four phases were observed between 25 and $150{ }^{\circ} \mathrm{C}$, indicating ethanol 
and water evaporation. Two more phases were identified in the range of $150-550{ }^{\circ} \mathrm{C}$ with a mass loss of $\sim 45 \%$. Further, above $550^{\circ} \mathrm{C}$, the mass loss was negligible. The DTG curve for the extraction sludge displays several decomposition steps; the peak at $300^{\circ} \mathrm{C}$ is more likely owing to the decomposition of hemicellulose [36]. The press mud and the vinasse powder showed an active pyrolysis zone in the range of $200-470^{\circ} \mathrm{C}$, where maximum weight loss occurred, while the passive pyrolysis zone was in the range of $450{ }^{\circ} \mathrm{C}-650{ }^{\circ} \mathrm{C}$ for the press mud sample and in a wider range for vinasse. Regarding the latter, the thermal degradation of the sample was not complete, even at $1000{ }^{\circ} \mathrm{C}$, owing to its complex composition. In contrast, the extraction sludge showed an active pyrolysis zone between 150 and $550{ }^{\circ} \mathrm{C}$ with a passive pyrolysis zone in a higher range $\left(550-1000^{\circ} \mathrm{C}\right)$. Similar results have been reported for the thermogravimetric behavior of the dried solid waste of post-methanated distillery effluent [37].

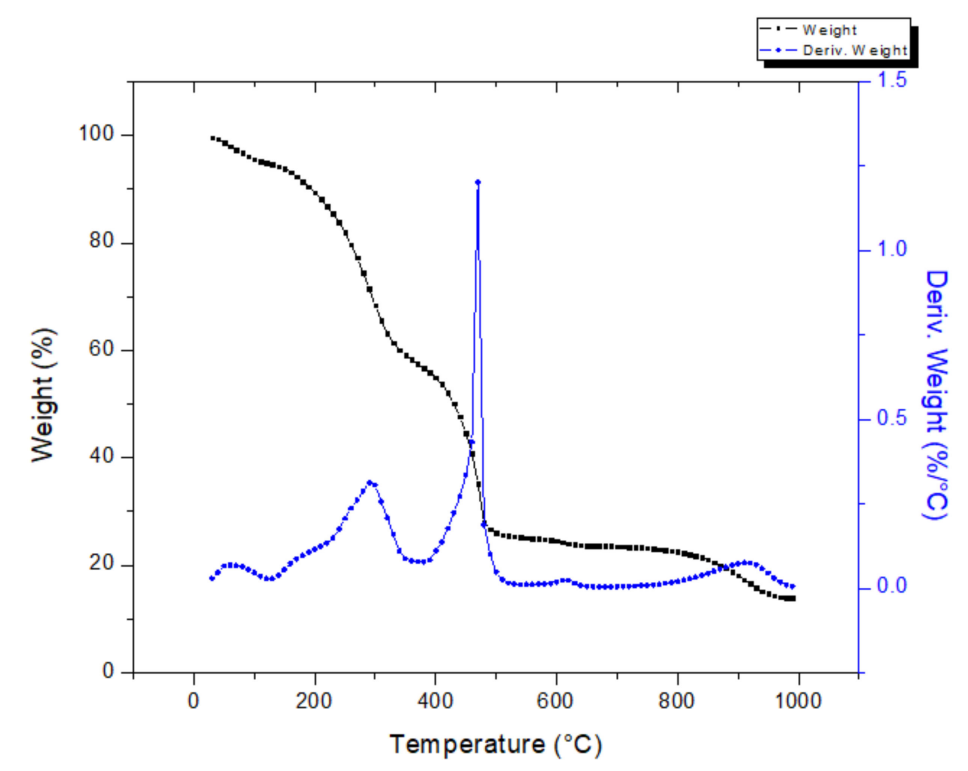

Figure 6. Thermogravimetric analysis of vinasse powder.

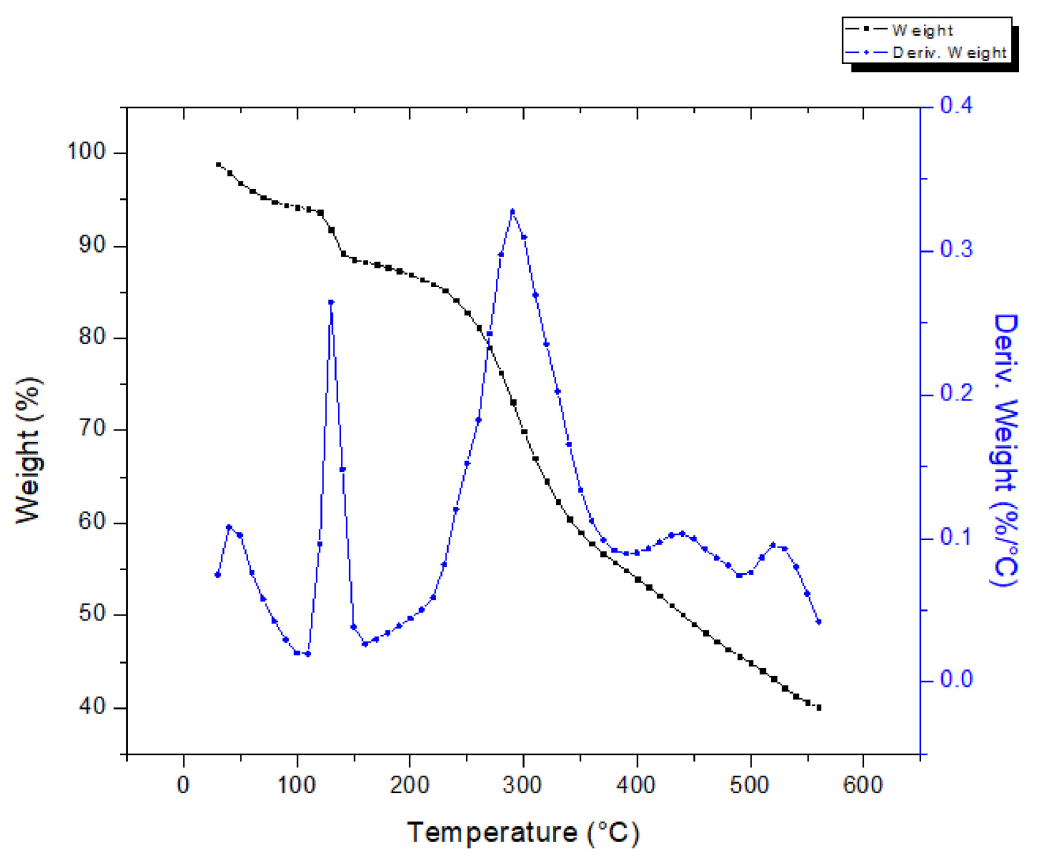

Figure 7. Thermogravimetric analysis of extraction sludge. 


\subsection{Slow Pyrolysis of Waste Biomass}

\subsubsection{Influence of Biomass Type on Pyrolysis Product Distribution}

Figure 8 presents the difference in pyrolysis products yield when each type of biomass waste-press mud, powder vinasse, and extraction sludge-was used as feedstock for slow pyrolysis. The liquid product was divided into heavy fraction and water (collected in the first two condensers of the pyrolysis unit) and light fraction (collected in the other two condensers). The gas yield was calculated as the mass difference between feedstock, liquid, and char yields.

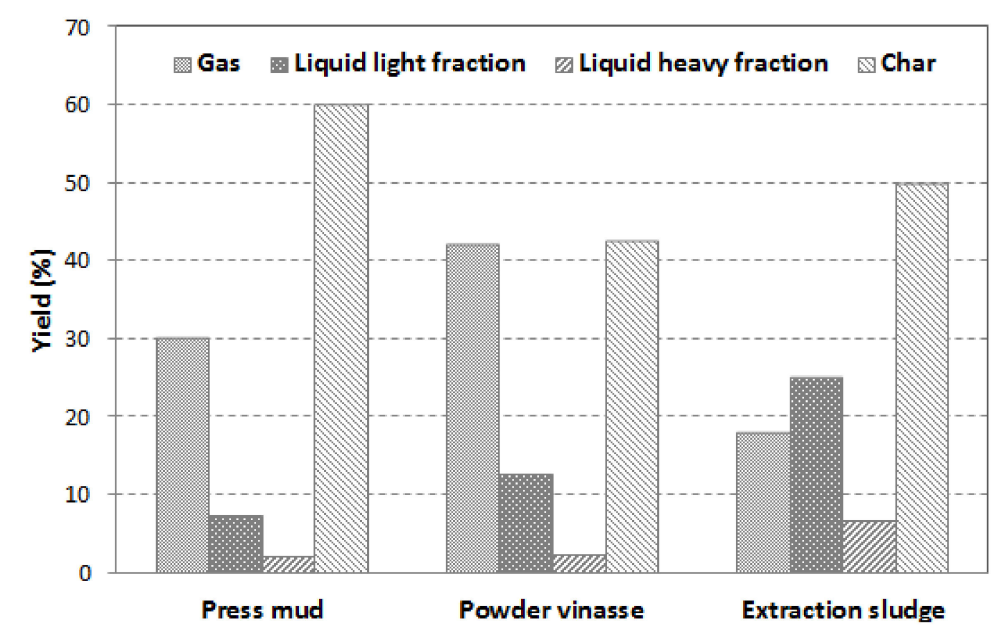

Figure 8. Effect of biomass waste type on product distribution at $450{ }^{\circ} \mathrm{C}$.

The results obtained show significant differences between the three waste biomass samples subjected to pyrolysis. It was observed that powder vinasse led to the formation of the lowest content of bio-char $(42.7 \%)$ and the highest production of volatiles. The results are confirmed by the proximate analysis of the raw biomass samples where powder vinasse showed the highest volatiles content (61.6 wt.\%) and the lowest ash content (20.5 wt.\%).

Meanwhile, the extraction sludge presented the highest liquid yield (32\%) with the lowest gas formation (18.2 wt.\%), which is likely owing to the high water content in the extraction sludge (7.5 wt.\%). This is consistent with the extraction sludge high heavy fraction yield (6.8 wt.\%), low content of volatiles (47.8 wt.\%), and high ash content (40.1 wt.\%).

The press mud presented the greatest char yield (60.1\%) owing to its initial high ash content $(53.8 \%)$. The elevated char yield of all biomass samples could suggest an incomplete decomposition of the organic phase at $450{ }^{\circ} \mathrm{C}$.

Similar product distributions of biomass wastes through slow pyrolysis were presented by other studies [38-42]. Agar et al. [38] converted wastewater sludge and organic fines from municipal wastewater treatment plants (similar volatiles and ash content as our biomass feedstock) in carbon-rich char through pyrolysis in a laboratory fixed-bed reactor at $600{ }^{\circ} \mathrm{C}$ and $700{ }^{\circ} \mathrm{C}$. The product distribution of sewage sludge at $600{ }^{\circ} \mathrm{C}$ was gas fraction $19 \%$, liquid $33 \%$, and char $48 \%$, while for solid organic fines, the product yields at the same temperature were gas $33 \%$, liquid $14 \%$, and char $53 \%$. Even at $700{ }^{\circ} \mathrm{C}$, the char produced was $45 \%$ for the sewage sludge feedstock, while the gas yield increased to $29 \%$. Williams and Besler [39] studied the influence of temperature and heating rate on the slow pyrolysis of biomass wood. The pyrolysis experiments were performed for $2 \mathrm{~h}$ at temperatures ranging from 300 to $720^{\circ} \mathrm{C}$, and heating rates of $5-80^{\circ} \mathrm{C} / \mathrm{min}$. The wood biomass presented a moisture of $7 \mathrm{wt} . \%$, volatiles of $92.2 \mathrm{wt} . \%$, and ash of $0.8 \mathrm{wt} . \%$. At $420{ }^{\circ} \mathrm{C}$ and a heating rate of $5{ }^{\circ} \mathrm{C} / \mathrm{min}$ (similar to our experimental conditions), the compositions were $29.7 \%$ for char, $12.4 \%$ for oil, $35.9 \%$ for the aqueous fraction, and $21.5 \%$ for gas. At higher operating temperatures, the char proportion decreased to $23.2 \%$, while the gas increased to $26.8 \%$. Increasing the heating rate promoted the gas yield, but decreased the 
oil yield. Al Arni [40] obtained a product distribution of 37.6\% char, $26.1 \%$ liquid, and $25.1 \%$ gas from sugarcane bagasse ( $84 \mathrm{wt} . \%$ volatiles, $5.9 \mathrm{wt} . \%$ ash) by conventional pyrolysis at $480{ }^{\circ} \mathrm{C}$, heating rates of $40-50^{\circ} \mathrm{C} / \mathrm{min}$, and $1 \mathrm{~h}$ residence time.

\subsubsection{Influence of Biomass Type on Bio-Char Composition}

The bio-char obtained after each pyrolysis test was analyzed in terms of moisture, $\mathrm{C}, \mathrm{H}, \mathrm{N}$, and $\mathrm{S}$ contents, as well as FTIR analysis. The compositions of the bio-char samples are shown in Table 3.

Table 3. Proximate and ultimate analysis of char produced from each type of biomass.

\begin{tabular}{cccccc}
\hline Feedstock & Moisture, wt $\%$ & $\mathbf{C ,} \%$ & $\mathbf{H}, \mathbf{\%}$ & $\mathbf{N}, \mathbf{\%}$ & $\mathbf{S}, \mathbf{\%}$ \\
\hline Press mud & 0.034 & 18.12 & 1.823 & 4.379 & 0 \\
Powder vinasse & 0 & 38.804 & 1.639 & 1.16 & 0 \\
Extraction sludge & 0.042 & 29.364 & 1.594 & 0.16 & 0 \\
\hline
\end{tabular}

After pyrolysis at $450{ }^{\circ} \mathrm{C}$ for $2 \mathrm{~h}$, the moisture content in all char samples decreased to almost $0 \%$. The results are also correlated with hydrogen content that decreased in all samples after pyrolysis. The sulfur content was not detected in any bio-char sample, suggesting that organic sulfur components were reduced to light fractions of the increase of gas yield bio-oil or gas. The char produced from powder vinasse was the richest in carbon (favorable as fuel and activated carbon). The increase of carbon content after pyrolysis was also observed by Parthasarathy and Sheeba [41] and Lee et al. [43]; these authors also associated the release of volatiles, such as hydrogen and oxygen by dehydrogenation and deoxygenation, to the relative increase of carbon content. In comparison, the pyrolysis of rubber wood at $550{ }^{\circ} \mathrm{C}$ showed a bio-char yield of $28.0 \% \pm 0.35 \%$ and a moisture content of $7.5 \%$ [44]

FTIR spectra of each waste biomass sample and their corresponding chars are presented in Figure 9. Four regions were detected on FTIR spectra of all biomass feedstock samples: in the range of 3000-3800 cm $\mathrm{cm}^{-1}$, between 2750 and $3000 \mathrm{~cm}^{-1}$, a region between 1500 and $1800 \mathrm{~cm}^{-1}$, and between 750 and $1250 \mathrm{~cm}^{-1}$. The small peak that appears at $3750-3970 \mathrm{~cm}^{-1}$ can be related to the presence of water in all biomass samples, while the broad peaks with maximum intensity around $3420 \mathrm{~cm}^{-1}$ can be attributed to $\mathrm{O}-\mathrm{H}$ stretching from aromatic and aliphatic alcohols, in particular, lignin [45]. The small peak from $2920-2930 \mathrm{~cm}^{-1}$ is characteristic of C-H stretching of methyl and methylene groups from cellulose, hemicellulose, and lignin.

The peaks in the region of $1500-1750 \mathrm{~cm}^{-1}$ correspond to $\mathrm{C}=\mathrm{O}$ stretching of ketones, aldehydes, esters from hemicellulose, and lignin [45,46]. Powder vinasse also shows an intense peak at $1417 \mathrm{~cm}^{-1}$, which is characteristic of $\mathrm{C}-\mathrm{H}$ deformation of the aromatic ring from lignin. The presence of this peak at higher intensity in the case of the powder vinasse could be the result of the higher content of lignin in this biomass sample. The peaks from $1033-1180 \mathrm{~cm}^{-1}$ can be attributed to C-O stretching from cellulose and hemicellulose.

Significant changes of FTIR spectra appear in the case of all bio-char samples obtained after slow pyrolysis at $450{ }^{\circ} \mathrm{C}$ for $2 \mathrm{~h}$. The $\mathrm{OH}$ stretching band from $3750-3970 \mathrm{~cm}^{-1}$ decreased drastically in the case of all char samples, disappearing completely in the case of char from extraction sludge (with the lowest content of lignin of $12.7 \%$ ). The absence of a peak at the $2920-2930 \mathrm{~cm}^{-1}$ range suggests a significant decomposition of the biomass material during pyrolysis [47]. While the bio-char produced from press mud still shows the peaks characteristic to $\mathrm{C}-\mathrm{O}$ stretching at almost the same intensity as the feedstock, the other two char samples show a significant decrease of the peaks from this region, suggesting the higher degradation of the organic compounds for these two biomass samples. 


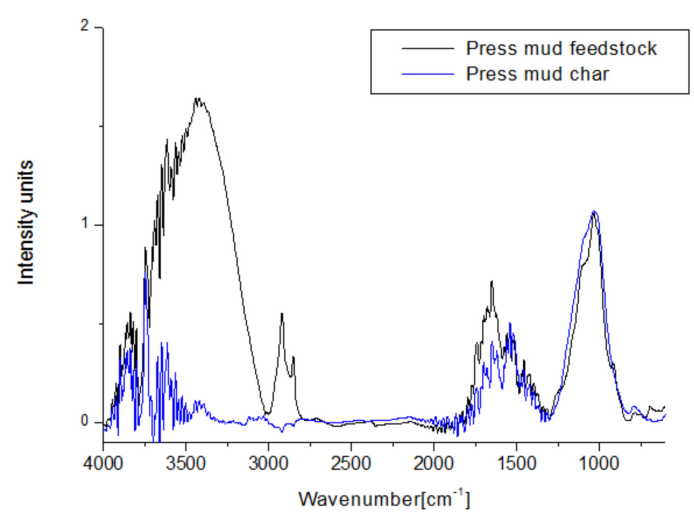

(a)

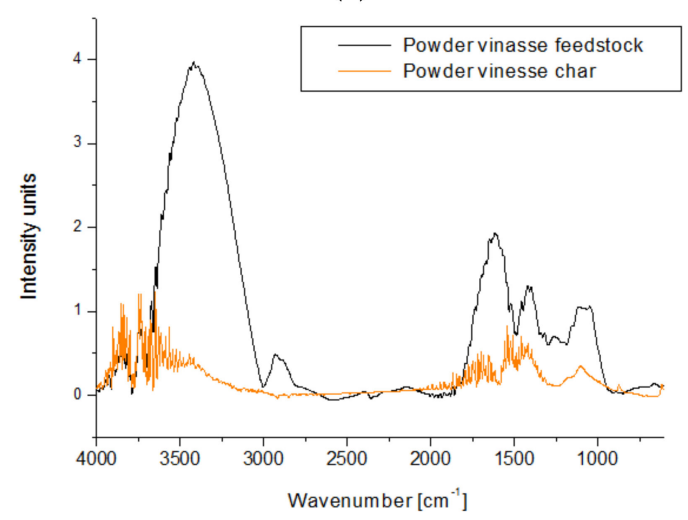

(b)

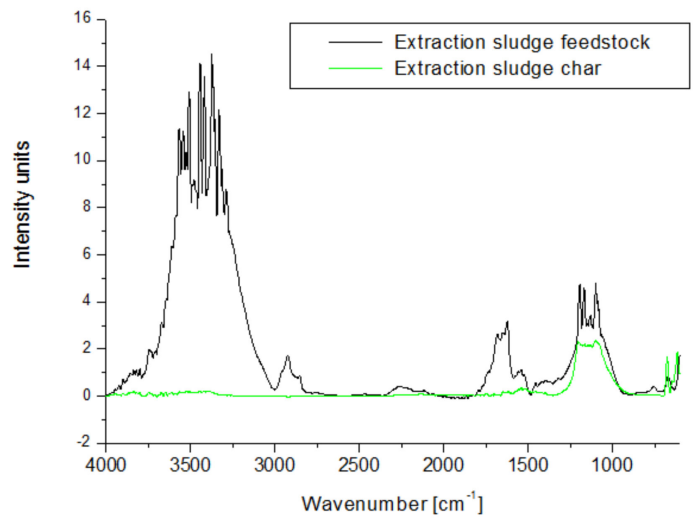

(c)

Figure 9. (a-c) FTIR spectra of waste biomass feedstock and bio-char after slow pyrolysis at $450{ }^{\circ} \mathrm{C}$ for $2 \mathrm{~h}$.

\subsubsection{Influence of Biomass Type on Bio-Oil Composition}

The bio-oils produced from each biomass waste pyrolysis were analyzed in terms of chemical composition using the gas chromatography mass spectrometer (GC-MS) technique. For each test, the liquid phase was extracted separately from each condenser of the cooling unit and analyzed with GC-MS; the reason for analyzing separately was to observe the way the organic components condensed in the cooling unit, as well as to obtain a more precise identification of the organic components.

The oil collected from condenser 1 (heavy fraction and water collector) showed a wide variety of organic components in the case of the powder vinasse and the extraction sludge, and fewer components for the press mud (Table 4). 
This section may be divided by subheadings. It should provide a concise and precise description of the experimental results, their interpretation, as well as the experimental conclusions that can be drawn.

Table 4. Composition of bio-oil collected on the first condenser (heavy fraction and water) of the pyrolysis unit.

\begin{tabular}{|c|c|c|c|c|c|}
\hline Press Mud & Rel. \% & Powder Vinasse & Rel. \% & Extraction Sludge & Rel. \% \\
\hline $\begin{array}{l}\text { Propanoic acid. } \\
\text { 2-hydroxy-. } \\
\text { methyl ester }\end{array}$ & 2.54 & $\begin{array}{l}\text { Propanoic acid. } \\
\text { 2-hydroxy-. methyl } \\
\text { ester. }\end{array}$ & 2.72 & $\begin{array}{c}\text { Oxalic acid. } \\
\text { dicyclobutyl ester }\end{array}$ & 8.08 \\
\hline 1-Hydroxy-2-butanone & 0.86 & 1-Hydroxy-2-butanone & 0.72 & Proline & 5.9 \\
\hline $\begin{array}{l}\text { Propane. } \\
\text { 2.2-diethoxy }\end{array}$ & 79.48 & $\begin{array}{l}\text { 2-Butanone } \\
\text { compounds }\end{array}$ & 0.27 & $\begin{array}{c}\text { Oxazole. } \\
\text { 4.5-dihydro-2.4.4-trimethyl }\end{array}$ & 3.1 \\
\hline $\begin{array}{l}\text { 2-Propanone. } \\
\text { 1.1-dimethoxy }\end{array}$ & 0.43 & $\begin{array}{c}\text { Pyrrolidine. } \\
\text { 2-(hydroxymethyl)- }\end{array}$ & 1.21 & $\begin{array}{l}\text { Hexanedioic acid. } \\
\text { monoethyl ester }\end{array}$ & 0.36 \\
\hline $\begin{array}{l}\text { 2-Cyclopenten-1-one } \\
\text { compounds }\end{array}$ & 4.95 & $\begin{array}{l}\text { 2-Cyclopenten-1-one } \\
\text { compounds }\end{array}$ & 3.74 & $\begin{array}{l}\text { 2-Cyclopenten-1-one } \\
\text { compounds }\end{array}$ & 4.48 \\
\hline Furfural & 1.51 & Acetamide & 0.23 & Indolizine & 1.89 \\
\hline $\begin{array}{l}\text { 2-Propanone. } \\
\text { 1-(acetyloxy) }\end{array}$ & 3.73 & Oxazole & 32.43 & $\begin{array}{l}\text { 2-Pentanone. } \\
\text { 4-hydroxy-4-methyl- }\end{array}$ & 3.52 \\
\hline 2-Furancarboxaldehyde & e 0.9 & $\begin{array}{l}\text { Acetaldehyde. } \\
\text { ethylidenehydrazone }\end{array}$ & 3.87 & $\begin{array}{l}\text { Hexadecanoic acid. } \\
\text { ethyl ester }\end{array}$ & 0.31 \\
\hline $\begin{array}{l}\text { Phenol } \\
\text { compounds }\end{array}$ & 3.33 & Phenol compounds & 13.36 & Phenol compounds & 16.11 \\
\hline $\begin{array}{l}\text { Benzofuran. } \\
\text { 2.3-dihydro }\end{array}$ & 0.28 & $\begin{array}{l}\text { Benzofuran. } \\
\text { 2.3-dihydro- }\end{array}$ & 1.6 & $\begin{array}{l}\text { Butanenitrile. } \\
\text { 2-methyl- }\end{array}$ & 2.52 \\
\hline $\begin{array}{l}\text { Alkanes } \\
\text { (C12-C18) }\end{array}$ & 1.26 & $\begin{array}{l}\text { Aziridine } \\
\text { compounds }\end{array}$ & 18.39 & $\begin{array}{l}\text { Aziridine } \\
\text { compounds }\end{array}$ & 18.17 \\
\hline $\begin{array}{l}\text { Alkenes } \\
\text { (C12-C15) }\end{array}$ & 0.27 & $\begin{array}{l}\text { 1.2-Ethanediol. } \\
\text { monoacetate }\end{array}$ & 0.47 & Alkanes (C12-C25) & 8.11 \\
\hline $\begin{array}{l}\text { Hexadecanoic } \\
\text { acid. methyl } \\
\text { ester }\end{array}$ & 0.15 & 2-Furanmethanol & 5.37 & Alkenes (C13-C18) & 3.47 \\
\hline \multirow[t]{5}{*}{$\begin{array}{l}\text { n-Hexadecanoic } \\
\text { acid }\end{array}$} & 0.12 & Pyrazine compounds & 1.61 & 2-Furanmethanol & 12.6 \\
\hline & & $\begin{array}{l}\text { Furanone } \\
\text { compounds }\end{array}$ & 1.32 & $\begin{array}{l}\text { Pyrazine } \\
\text { compounds }\end{array}$ & 3.90 \\
\hline & & $\begin{array}{l}\text { 1.2-Cyclopentanedione. } \\
\text { 3-methyl }\end{array}$ & 1.94 & Others & 7.52 \\
\hline & & Caprolactam & 1.96 & & \\
\hline & & Others & 9.04 & & \\
\hline
\end{tabular}

Similar compounds were obtained from all three biomass waste samples, although with significant differences in terms of concentration. The powder vinasse and the extraction sludge showed a high concentration of nitrogen compounds, related to the higher $\mathrm{N}$ content observed in these two samples. The liquid obtained from the press mud showed a significant amount of 2.2-dimethoxypropane (DMP) - the compound is generally formed from acetone and methanol at room temperature in the presence of an acidic environment [48]. Small amounts of 2-cyclopenten-1-one, phenolic compounds, as well as alkanes (C12-C18) were also observed.

In the case of the powder vinasse, oxazole and aziridine compounds (both with nitrogen in their structure) were in the highest concentration-50.8\%, along with phenolic compounds (13.4\%) and furanmethanol (5.4\%). While the powder vinasse did not show any alkanes or alkenes, it contained a significantly higher concentration of aromatics than the liquid from the press mud. Similar results have been obtained by David et al. [49] from pyrolysis of sugarcane bagasse.

The extraction sludge showed the highest concentration of phenols $(16.1 \%)$, aziridines and pyrazines $(22.1 \%)$, and furanmethanol $(12.6 \%)$, as well as the most elevated content of alkanes and 
alkenes (11.6\%). In the second condenser of the cooling unit, heavier organic compounds were observed in the composition of the pyrolysis liquids (Table 5).

Table 5. Composition of bio-oil collected from the second condenser of the pyrolysis unit.

\begin{tabular}{|c|c|c|c|c|c|}
\hline Press Mud & Rel.\% & $\begin{array}{l}\text { Powder } \\
\text { Vinasse }\end{array}$ & Rel.\% & $\begin{array}{l}\text { Extraction } \\
\text { Sludge }\end{array}$ & Rel.\% \\
\hline $\begin{array}{c}\text { Phenol } \\
\text { compounds }\end{array}$ & 31.99 & $\begin{array}{c}\text { Phenol } \\
\text { compounds }\end{array}$ & 54.61 & $\begin{array}{c}\text { Phenol } \\
\text { compounds }\end{array}$ & 49.83 \\
\hline Oxazole.4.5-dihydro & 6.54 & $\begin{array}{l}\text { Penten-2-one } \\
\text { compounds }\end{array}$ & 8.24 & $\begin{array}{l}\text { 3-Penten-2-one. } \\
\text { 4-methyl- }\end{array}$ & 2.02 \\
\hline $\begin{array}{l}\text { 2-Cyclopenten-1-one } \\
\text { comp. }\end{array}$ & 7.81 & $\begin{array}{l}\text { Propanoic acid. } \\
\text { 2-hydroxy }\end{array}$ & 0.19 & Cyclopentanone & 3.12 \\
\hline Furfural & 1.31 & 2.3-Butanediol. & 1.09 & 2-Isopropylpyrazine & 9.69 \\
\hline $\begin{array}{l}\text { 2-Pentanone. } \\
\text { 4-hydroxy-4-methyl- }\end{array}$ & 1.7 & $\begin{array}{l}\text { 2-Pentanone. } \\
\text { 4-hydroxy-4-methyl- }\end{array}$ & 2.46 & $\begin{array}{l}\text { 2-Pentanone.4- } \\
\text { hydroxy-4-methyl- }\end{array}$ & 9.58 \\
\hline $\begin{array}{l}\text { 2-Propanone. } \\
\text { 1-(acetyloxy) }\end{array}$ & 4.17 & 2-Furanmethanol & 0.5 & $\begin{array}{l}\text { N-Cyano-2- } \\
\text { methylpyrrolidine }\end{array}$ & 1.48 \\
\hline Cyclooctane & 2.19 & $\begin{array}{l}\text { 2-Propen-1-amine. } \\
\text { N.N-bis(1-methylethyl) }\end{array}$ & 1.47 & Toluene & 2.66 \\
\hline $\begin{array}{l}\text { 2-Furancarboxaldehyde. } \\
\text { 5-methyl- }\end{array}$ & 1.53 & $\begin{array}{l}\text { Piperidine. } \\
\text { 1.2-dimethyl- }\end{array}$ & 0.35 & $\begin{array}{l}\text { 1.6-Dioxacyclododecane- } \\
\text { 7.12-dione }\end{array}$ & 1.44 \\
\hline $\begin{array}{l}\text { Benzofuran. } \\
\text { 2.3-dihydro- }\end{array}$ & 3.09 & $\begin{array}{l}\text { Benzofuran. } \\
\text { 2.3-dihydro }\end{array}$ & 4.97 & $\begin{array}{l}\text { Hexanedioic acid. } \\
\text { ethyl.methyl es }\end{array}$ & 0.46 \\
\hline $\begin{array}{l}\text { 1.2-Cyclopentanedione. } \\
\text { 3-methyl- }\end{array}$ & 3.74 & $\begin{array}{l}\text { 1.2-Cyclopentanedione. } \\
\text { 3-methyl }\end{array}$ & 1.88 & Indolizine & 6.11 \\
\hline $\begin{array}{l}\text { Alkanes } \\
(\mathrm{C} 13-\mathrm{C} 22)\end{array}$ & 25.09 & $\begin{array}{c}\text { Alkanes } \\
\text { (C19-C32) }\end{array}$ & 4.29 & $\begin{array}{l}\text { Alkanes } \\
(\mathrm{C} 16-\mathrm{C} 25)\end{array}$ & 6.68 \\
\hline $\begin{array}{l}\text { Alkenes } \\
\text { (C14-C16) }\end{array}$ & 3.19 & $\begin{array}{l}\text { 2-Amino-5.6-dihydro- } \\
\text { 4.4.6-trimethyl-4H-1.3 } \\
\text {-oxazine }\end{array}$ & 4.12 & $\begin{array}{l}\text { Alkenes } \\
\text { (C16-C25) }\end{array}$ & 2.57 \\
\hline $\begin{array}{l}\text { Palmitic acid. } \\
\text { methyl ester }\end{array}$ & 1.2 & $\begin{array}{l}\text { Indole } \\
\text { compounds }\end{array}$ & 2.29 & $\begin{array}{l}\text { 1H-Indole. } \\
\text { 3-methyl- }\end{array}$ & 1.51 \\
\hline $\begin{array}{l}\text { Hexadecanoic } \\
\text { acid. propyl ester }\end{array}$ & 0.63 & $\begin{array}{l}\text { 4-Piperidinone. } \\
\text { 2.2.6.6-tetramethyl- }\end{array}$ & 1.03 & Others & 2.85 \\
\hline Others & 5.81 & $\begin{array}{l}\text { Thymol } \\
\text { Others }\end{array}$ & $\begin{array}{c}0.66 \\
11.82\end{array}$ & & \\
\hline
\end{tabular}

For all of the samples, the main components of the liquid collected from the second condenser were phenolic compounds that were produced by the degradation of lignin. Powder vinasse and extraction sludge showed $50 \%$ of phenolic compounds, which is a very similar result to those reported in the literature [49-51]. The liquid fraction obtained from the press mud pyrolysis contained the highest proportion of alkanes (25.1\%), although powder vinasse presented heavier alkenes, up to C32. A higher content of ketones (aliphatic and cyclic) was formed when the press mud (13.7\%) and the extraction sludge $(14.7 \%)$ were used for pyrolysis.

The liquid extracted from the last two condensers showed a variety of components, including heavy and volatile compounds. A significant amount of phenols was still observed in the liquid collected at the third condenser.

The liquid from the press mud collected in the third condenser (Table 6) also showed a high content of alkanes, phenols, and ketones, similar to the compounds gathered in the previous condenser. For the powder vinasse, the main components observed were ketones (38\%); phenols (16.1\%); and organic compounds based on nitrogen (17.6\%) - azirides, pyrroles, piperidines, and pyrazines. The extraction sludge showed a lower content of ketones (17.5\%) and phenols $(15.7 \%)$, but a higher content of organic nitrogen compounds $(29.9 \%)$ and alkanes $(6.5 \%)$. The liquids obtained from the pyrolysis of the press mud and the extraction sludge seemed to be, in general, heavier than that obtained from powder vinasse. 
Table 6. Composition of bio-oil collected at the third condenser of the pyrolysis unit.

\begin{tabular}{|c|c|c|c|c|c|}
\hline Press Mud & Rel.\% & Powder Vinasse & Rel.\% & $\begin{array}{l}\text { Extraction } \\
\text { Sludge }\end{array}$ & Rel.\% \\
\hline $\begin{array}{l}\text { Propane. } \\
\text { 2.2-diethoxy }\end{array}$ & 8.26 & $\begin{array}{l}\text { Propanoic acid. } \\
\text { 2-hydroxy-. } \\
\text { methyl ester. }\end{array}$ & 0.52 & Cyclopentanone & 1.20 \\
\hline $\begin{array}{l}\text { 2-Cyclopenten-1-one } \\
\text { compounds }\end{array}$ & 10.49 & $\begin{array}{l}\text { Penten-2-one } \\
\text { compounds }\end{array}$ & 24.82 & Oxazole & 3.64 \\
\hline Furfural & 5.24 & $\begin{array}{l}\text { Pyrrolidine. } \\
\text { 2-(hydroxymethyl)- }\end{array}$ & 0.41 & $\begin{array}{l}\text { 3-Penten-2-one. } \\
\text { 4-methyl }\end{array}$ & 2 \\
\hline $\begin{array}{l}\text { Propanoic acid. } \\
\text { 2-oxo-. ethyl } \\
\text { ester }\end{array}$ & 4.13 & 2.3-Butanediol & 1.39 & $\begin{array}{l}\text { Acetaldehyde. } \\
\text { ethylidenehydrazone }\end{array}$ & 4.56 \\
\hline $\begin{array}{l}\text { 2-Furancarboxaldehyde. } \\
\text { 5-methyl- }\end{array}$ & 2.37 & $\begin{array}{l}\text { Acetaldehyde. } \\
\text { ethylidenehydrazone }\end{array}$ & 3.48 & $\begin{array}{l}\text { 5-Hexenenitrile. } \\
\text { 2-methyl }\end{array}$ & 4.49 \\
\hline $\begin{array}{l}\text { Carbamic acid. } \\
\text { phenyl ester }\end{array}$ & 5.42 & $\begin{array}{l}\text { 2-Cyclopenten-1-one } \\
\text { compounds }\end{array}$ & 2.29 & $\begin{array}{l}\text { 2-Pentanone. } \\
\text { 4-hydroxy-4-methyl }\end{array}$ & 13.14 \\
\hline $\begin{array}{l}\text { 1.2-Cyclopentanedione. } \\
\text { 3-methyl- }\end{array}$ & 3.48 & $\begin{array}{l}\text { Glycine. } \\
\text { N-(aminoiminomethyl)- } \\
\text { N-methyl- }\end{array}$ & 1.97 & 2-Furanmethanol & 5.64 \\
\hline $\begin{array}{l}\text { Phenol } \\
\text { compounds }\end{array}$ & 13.54 & $\begin{array}{l}\text { Pentanone. } \\
\text { 4-hydroxy-4-methyl- }\end{array}$ & 11.52 & $\begin{array}{l}\text { Aziridine } \\
\text { compounds }\end{array}$ & 4.97 \\
\hline Larixic acid & 0.71 & 2-Furanmethanol & 2.03 & $\begin{array}{l}\text { Pyrazine. } \\
\text { 2.6-dimethyl- }\end{array}$ & 1.20 \\
\hline $\begin{array}{l}\text { Benzaldehyde. } \\
\text { 4-methyl- }\end{array}$ & 3.83 & $\begin{array}{l}\text { Aziridine. } \\
\text { 2-(1.1-dimethylethyl)- } \\
\text { 1.3-dimethyl- }\end{array}$ & 3.81 & $\begin{array}{l}\text { N-Cyano-2- } \\
\text { methylpyrrolidine }\end{array}$ & 1.25 \\
\hline $\begin{array}{l}\text { Alkanes } \\
\text { (C13-C26) }\end{array}$ & 20.85 & $\begin{array}{l}\text { Pyrrole. } \\
\text { 1-methyl-3-(1.1- } \\
\text { dimethylethyl)- }\end{array}$ & 1.03 & $\begin{array}{l}\text { 2-Cyclopenten-1-one. } \\
\text { 3-methyl- }\end{array}$ & 1.16 \\
\hline $\begin{array}{l}\text { Alkenes } \\
\text { (C14-C26) }\end{array}$ & 5.53 & $\begin{array}{l}\text { Phenol } \\
\text { compounds }\end{array}$ & 16.07 & $\begin{array}{l}\text { 1-Heptene. } \\
\text { 2.6-dimethyl- }\end{array}$ & 1.59 \\
\hline $\begin{array}{l}\text { Hexadecanoic } \\
\text { acid. methyl } \\
\text { ester }\end{array}$ & 2.52 & $\begin{array}{l}\text { Pyrazine } \\
\text { compounds }\end{array}$ & 1.28 & $\begin{array}{c}\text { Phenol } \\
\text { compounds }\end{array}$ & 15.70 \\
\hline $\begin{array}{l}\text { Octadecanoic } \\
\text { acid. 2-propenyl } \\
\text { ester }\end{array}$ & 0.44 & $\begin{array}{l}\text { Piperidine } \\
\text { compounds }\end{array}$ & 0.37 & $\begin{array}{l}\text { Piperazine. } \\
\text { 2.5-dimethyl-. } \\
\text { trans }\end{array}$ & 10.93 \\
\hline \multirow[t]{6}{*}{ Others } & \multirow[t]{6}{*}{13.19} & Caprolactam & 1.20 & $\begin{array}{l}\text { Pyrazole. } \\
\text { 1.4-dimethyl }\end{array}$ & 2.73 \\
\hline & & $\begin{array}{l}\text { 2-Propen-1-amine. } \\
\text { N.N-bis(1-methylethyl) }\end{array}$ & 3.72 & $\begin{array}{l}\text { 2.2.6.6-Tetramethyl-4- } \\
\text { piperidone }\end{array}$ & 4.39 \\
\hline & & $\begin{array}{l}\text { 4-Piperidinone. } \\
\text { 2.2.6.6-tetramethyl- }\end{array}$ & 11.09 & $\begin{array}{l}\text { Alkanes } \\
\text { (C13-C26) }\end{array}$ & 6.51 \\
\hline & & $\begin{array}{l}\text { Benzofuran. } \\
\text { 2.3-dihydro- }\end{array}$ & 1.36 & $\begin{array}{l}\text { Alkenes } \\
\text { (C13-C18) }\end{array}$ & 2.29 \\
\hline & & $\begin{array}{l}\text { Alkanes } \\
\text { (C18-C28) }\end{array}$ & 1.49 & $\begin{array}{l}\text { Hexadecanoic } \\
\text { acid ester }\end{array}$ & 0.68 \\
\hline & & Others & 9.84 & Others & 11.74 \\
\hline
\end{tabular}

In the case of the press mud, it was observed that the pyrolysis liquid from the fourth condenser presented a significant amount of volatiles-acetic acid and toluene (32.9\%). The proportion of furfural, benzene, and furan components was also significant (21\%), evidencing the decomposition of hemicellulose (Table 7). 
Table 7. Composition of the bio-oil collected at the fourth condenser of the pyrolysis unit.

\begin{tabular}{|c|c|c|c|c|c|}
\hline Press Mud & Rel.\% & $\begin{array}{l}\text { Powder } \\
\text { Vinasse }\end{array}$ & Rel.\% & Extraction Sludge & Rel.\% \\
\hline Acetic acid & 17.95 & $\begin{array}{l}\text { 2,4,4-Trimethyl-2- } \\
\text { oxazoline }\end{array}$ & 10.52 & 1,3-Butanediol & 2.92 \\
\hline $\begin{array}{c}\text { Toluene } \\
\text { compounds }\end{array}$ & 14.97 & $\begin{array}{l}\text { Toluene } \\
\text { compounds }\end{array}$ & 1.27 & Toluene & 30.86 \\
\hline Furfural & 10.96 & $\begin{array}{c}\text { Furfuryl } \\
\text { alcohol }\end{array}$ & 2.65 & $\begin{array}{c}\text { 2-Pentanone, } \\
\text { 4-hydroxy-4-methyl }\end{array}$ & 5.13 \\
\hline $\begin{array}{c}\text { Propane, } \\
\text { 2,2-diethoxy- }\end{array}$ & 0.46 & $\begin{array}{l}\text { Propanoic acid, } \\
\text { 2-hydroxy-, } \\
\text { methyl este }\end{array}$ & 1.06 & $\begin{array}{l}\text { Phthalic acid, } \\
\text { diethyl ester }\end{array}$ & 1.08 \\
\hline 2-Cyclopenten-1-one & 5.31 & $\begin{array}{l}\text { 2-Cyclopenten-1-one } \\
\text { compunds }\end{array}$ & 5.34 & $\begin{array}{l}\text { 1-Methyl-1-cyclopenten- } \\
\text { 3-one }\end{array}$ & 0.44 \\
\hline $\begin{array}{l}\text { Other aliphatic } \\
\text { ketones }\end{array}$ & 0.89 & $\begin{array}{l}\text { Other Aliphatic } \\
\text { ketones }\end{array}$ & 7.11 & $\begin{array}{l}\text { Other aliphatic } \\
\text { ketones }\end{array}$ & 0.5 \\
\hline $\begin{array}{l}\text { Other aromatic } \\
\text { ketones }\end{array}$ & 2.39 & $\begin{array}{l}\text { Other aromatic } \\
\text { ketones }\end{array}$ & 6.8 & $\begin{array}{l}\text { 2,2,6,6-Tetramethyl-4- } \\
\text { piperidinone }\end{array}$ & 2.92 \\
\hline $\begin{array}{l}\text { Benzene } \\
\text { compounds }\end{array}$ & 5.46 & Benzene & 0.12 & Ethylbenzene & 3.66 \\
\hline $\begin{array}{c}\text { Furan } \\
\text { compounds }\end{array}$ & 4.62 & $\begin{array}{c}\text { Furan } \\
\text { compounds }\end{array}$ & 2.87 & Furan compounds & 0.87 \\
\hline $\begin{array}{l}\text { Phenol } \\
\text { compounds }\end{array}$ & 3.96 & $\begin{array}{c}\text { Phenol } \\
\text { compounds }\end{array}$ & 18.91 & Phenol compounds & 4.18 \\
\hline $\begin{array}{l}\text { Octadecyl vinyl } \\
\text { ether }\end{array}$ & 2.26 & $\begin{array}{l}\text { Picoline } \\
\text { compounds }\end{array}$ & 2.16 & 2-Picoline & 2.03 \\
\hline $\begin{array}{l}\text { p-Methylbenzyl } \\
\text { alcohol }\end{array}$ & 1.36 & $\begin{array}{l}\text { Pyrazine } \\
\text { compounds }\end{array}$ & 2.3 & $\begin{array}{l}\text { Pyrazine } \\
\text { compunds }\end{array}$ & 2.15 \\
\hline $\begin{array}{l}\text { 3,5-Heptadien-2-ol, } \\
\text { 2,6-dimethyl }\end{array}$ & 1.1 & m-Xylene & 0.43 & Xylene compounds & 2.81 \\
\hline $\begin{array}{l}\text { Alkanes } \\
\text { (C8-C28) }\end{array}$ & 14.69 & $\begin{array}{c}\text { Xylenol } \\
\text { compounds }\end{array}$ & 2.87 & $\begin{array}{c}\text { Piridine } \\
\text { compounds }\end{array}$ & 0.57 \\
\hline $\begin{array}{l}\text { Alkenes } \\
\text { (C7-C22) }\end{array}$ & 6.56 & $\begin{array}{l}\text { 2-Methyl-2- } \\
\text { cyclopentenone }\end{array}$ & 3.13 & 2,5-Dimethylpiperazine & 8.56 \\
\hline \multirow[t]{6}{*}{ Other } & 7.06 & 2-Methylene-4-pentenal & 11.15 & Alkanes (C9-C27) & 9.11 \\
\hline & & $\begin{array}{l}\text { Pyridine } \\
\text { compounds }\end{array}$ & 2.57 & Alkenes (C12-C27) & 4.63 \\
\hline & & $\begin{array}{l}\text { Cycloheptanol, } \\
\text { 1-methyl-2-methylene- }\end{array}$ & 1.04 & Other & 17.61 \\
\hline & & $\begin{array}{l}\text { 4-(Ethylsulfanyl)-2- } \\
\text { butanone }\end{array}$ & 0.34 & & \\
\hline & & $\begin{array}{l}\text { Alkynes } \\
\text { (C5-C8) }\end{array}$ & 3.71 & & \\
\hline & & Other & 21.13 & & \\
\hline
\end{tabular}

The pyrolysis liquid from the powder vinasse still contained a significant amount of phenolic compounds (18.9\%), in particular, phenol, phenol methoxy, phenol methyl, and ethyl. Figure 10 shows the chromatogram of the pyrolysis liquid obtained from powder vinasse with the identification of the peaks characteristic to phenols. This sample contained a higher content of aliphatic and aromatic ketones $(19.2 \%)$ compared with the other two pyrolysis oils generated from the press mud and the extraction sludge. Moreover, the sample also showed the presence of alkynes and sulfur organic compounds; the powder vinasse presented the highest content of sulfur-1.47\%. The extraction sludge showed significant amounts of toluene, xylenes, and benzenes (37.3\%), as well as aliphatic and aromatic ketones (6\%), alkanes, and alkenes (13.7\%). 


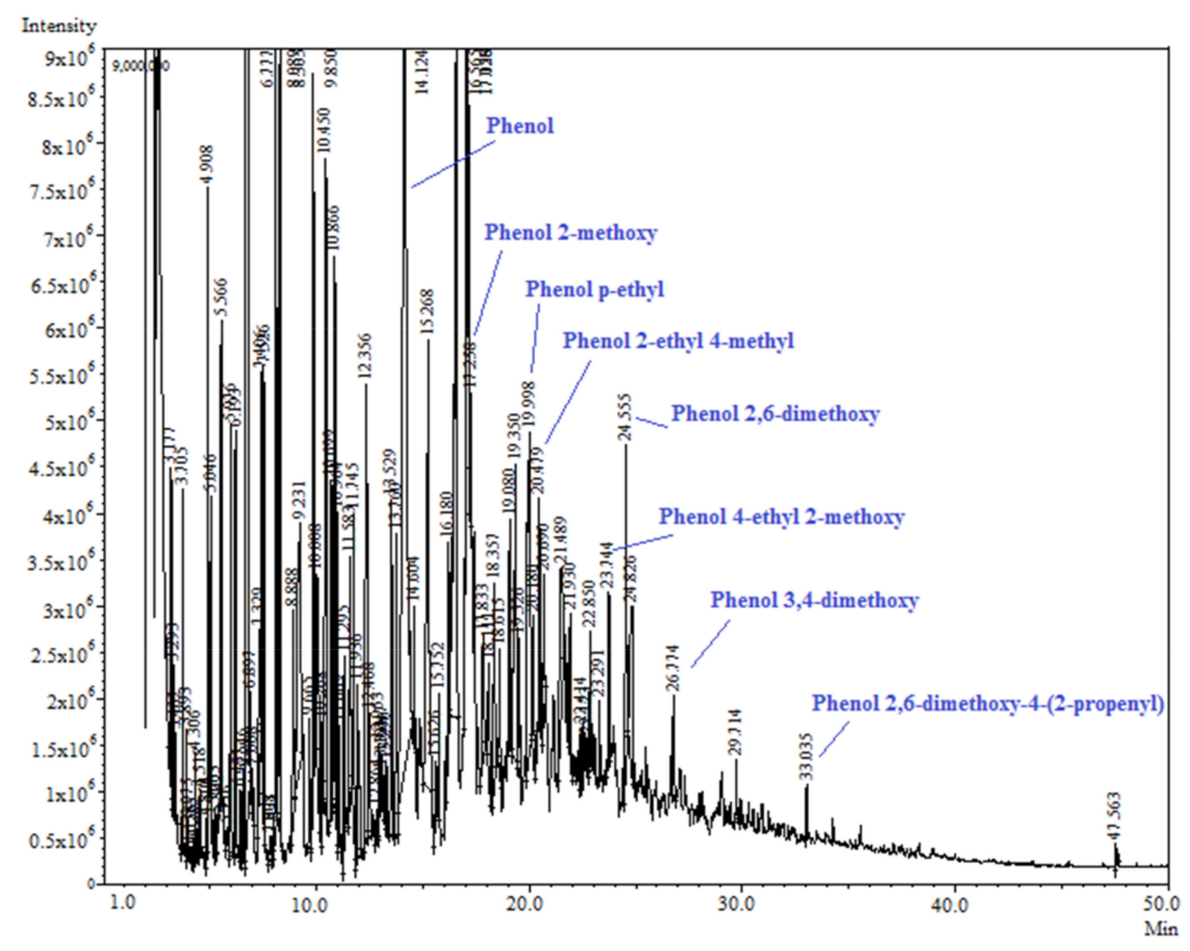

Figure 10. GC-MS analysis of condensed oil from the powder vinasse.

After individual analysis of pyrolysis liquids samples collected at each condenser, the overall composition of the pyrolysis bio-oil for each biomass waste feedstock was calculated, based on the concentration of each component and the quantity of liquid collected from each condenser. The main components found in each pyrolysis bio-oil are shown in Table 8. As a general observation, the powder vinasse produced a large variety of organic components owing to the thermal decomposition of the lignocellulosic compounds (with high volatiles content).

More than 200 components were identified in the liquid phases collected from each condenser; the separate GC-MS analysis eased the identification of all components. In the case of all three biomass samples, similar compounds were identified, in particular for the powder vinasse and the extraction sludge (high amount of organic components with nitrogen). The press mud produced important amounts of propane alkyloxy (propane, 2,2-diethoxy, 2-propanone, 1,1-dimethoxy, 2-propanone, 1-(acetyloxy)), carboxylic acids, furfural, toluene, and aliphatic and aromatic phenols, as well as alkanes and alkenes. The powder vinasse showed higher produced concentrations of phenolic, aliphatic, and aromatic ketones, as well as organic nitrogen compounds, compared with the bio-oil produced from the press mud. The bio-oil from the powder vinasse showed a high content of aromatics and a low content of hydrocarbons (alkanes, alkenes), which could have a positive impact on the physicochemical properties of the bio-oil.

Conversely, the main component of bio-oil from extraction sludge was toluene (more than $22 \%$ ) as well as phenolic and organic nitrogen compounds_azirides, piperazines, piridines, and indolizines. The content of hydrocarbons was also high for the bio-oil produced from the extraction sludge. 
Table 8. Overall composition of the pyrolysis bio-oil obtained from different biomass feedstock.

\begin{tabular}{|c|c|c|c|c|c|}
\hline Press Mud & Mass \% & Powder Vinasse & Mass \% & Extraction Sludge & Mass \% \\
\hline $\begin{array}{l}\text { Carboxylic acid } \\
\text { esters }\end{array}$ & 3.02 & $\begin{array}{c}\text { Carboxylic acid } \\
\text { esters }\end{array}$ & 1.32 & Carboxylic acid esters & 2.70 \\
\hline 1-Hydroxy-2-butanone & 0.20 & 1-Hydroxy-2-butanone & 0.12 & 5-Hexenenitrile, 2-methyl & 0.21 \\
\hline $\begin{array}{l}\text { Propane } \\
\text { +propanone, } \\
\text { alkyloxy- }\end{array}$ & 20.61 & $\begin{array}{l}\text { 2-Cyclopenten-1-one } \\
\text { compounds }\end{array}$ & 7.55 & $\begin{array}{l}\text { 2-Cyclopenten-1-one } \\
\text { compounds }\end{array}$ & 1.33 \\
\hline $\begin{array}{l}\text { 2-Cyclopenten-1-one } \\
\text { compounds }\end{array}$ & 5.62 & $\begin{array}{l}\text { Other Aliphatic } \\
\text { ketones }\end{array}$ & 6.96 & Other aliphatic ketones & 0.47 \\
\hline $\begin{array}{l}\text { 2-Pentanone, } \\
\text { 4-hydroxy-4-methyl- }\end{array}$ & 0.04 & $\begin{array}{l}\text { Other aromatic } \\
\text { ketones }\end{array}$ & 5.82 & $\begin{array}{l}\text { Other aromatic } \\
\text { compounds }\end{array}$ & 0.07 \\
\hline $\begin{array}{l}\text { 1,2-Cyclopentanedione, } \\
\text { 3-methyl- }\end{array}$ & 0.31 & Oxazole compounds & 13.70 & Oxazoles & 0.83 \\
\hline $\begin{array}{l}\text { Other aliphatic } \\
\text { ketones }\end{array}$ & 0.60 & Phenol compounds & 18.51 & Phenol compounds & 7.48 \\
\hline $\begin{array}{l}\text { Other aromatic } \\
\text { ketones }\end{array}$ & 1.62 & $\begin{array}{l}\text { Benzofuran, } \\
\text { 2,3-dihydro- }\end{array}$ & 0.35 & Ethylbenzene & 2.69 \\
\hline Furfural & 8.16 & $\begin{array}{l}\text { Aziridine } \\
\text { compounds }\end{array}$ & 3.12 & Aziridine compounds & 4.11 \\
\hline 2-Furancarboxaldehyde & le 0.40 & Furan compounds & 3.27 & Furan compounds & 3.59 \\
\hline $\begin{array}{l}\text { Phenol } \\
\text { compounds }\end{array}$ & 5.04 & Pyrazine compounds & 2.17 & Pyrazine compounds & 2.64 \\
\hline $\begin{array}{l}\text { Benzene } \\
\text { compounds }\end{array}$ & 4.63 & $\begin{array}{l}\text { Furanone } \\
\text { compounds }\end{array}$ & 0.21 & Piperazines & 6.80 \\
\hline $\begin{array}{l}\text { Furan } \\
\text { compounds }\end{array}$ & 3.14 & Caprolactam & 0.37 & Piridine compounds & 0.42 \\
\hline $\begin{array}{l}\text { Benzofuran, } \\
\text { 2,3-dihydro }\end{array}$ & 0.13 & $\begin{array}{c}\text { 2-Pentanone, } \\
\text { 4-hydroxy-4-methyl- }\end{array}$ & 0.54 & $\begin{array}{c}\text { 2-Pentanone, } \\
\text { 4-hydroxy-4-methyl- }\end{array}$ & 5.18 \\
\hline $\begin{array}{l}\text { Benzaldehyde, } \\
\text { 4-methyl- }\end{array}$ & 0.25 & Amines & 0.29 & Indolizine & 0.44 \\
\hline Acetic acid & 12.18 & $\begin{array}{l}\text { Acetaldehyde, } \\
\text { ethylidenehydrazone }\end{array}$ & 0.78 & $\begin{array}{l}\text { Acetaldehyde, } \\
\text { ethylidenehydrazone }\end{array}$ & 0.21 \\
\hline $\begin{array}{l}\text { n-Hexadecanoic } \\
\text { acid }\end{array}$ & 0.03 & $\begin{array}{l}\text { Piperidine } \\
\text { compounds }\end{array}$ & 0.53 & 2,2,6,6-Tetramethyl-4-piperidone & 2.35 \\
\hline Larixic acid & 0.05 & Toluene compounds & 1.03 & Toluene & 22.69 \\
\hline $\begin{array}{l}\text { Oxazole, } \\
4,5 \text {-dihydro }\end{array}$ & 0.14 & Indole compounds & 0.02 & Butanenitrile, 2-methyl- & 0.54 \\
\hline Cyclooctane & 0.05 & $\begin{array}{c}\text { Pyrrolidine, } \\
\text { 2-(hydroxymethyl)- }\end{array}$ & 0.21 & Proline & 1.26 \\
\hline $\begin{array}{l}\text { Toluene } \\
\text { compounds }\end{array}$ & 10.16 & Furfuryl alcohol & 2.14 & 2-Picoline & 1.49 \\
\hline $\begin{array}{l}\text { 3,5-Heptadien-2-ol, } \\
\text { 2,6-dimethyl }\end{array}$ & 0.75 & Picoline compounds & 1.75 & Xylene compounds & 2.06 \\
\hline $\begin{array}{l}\text { Alkanes } \\
(\mathrm{C} 12-\mathrm{C} 28)\end{array}$ & 12.16 & Xylenol compounds & 2.32 & 1,3-Butanediol & 2.15 \\
\hline $\begin{array}{l}\text { Alkenes } \\
(\mathrm{C} 12-\mathrm{C} 26)\end{array}$ & 4.94 & m-Xylene & 0.35 & Alkanes (C9-C27) & 8.76 \\
\hline \multirow[t]{9}{*}{ Others } & 5.78 & Pyridine compounds & 2.08 & Alkenes (C12-C27) & 4.26 \\
\hline & & 2,3-Butanediol, & 0.07 & Others & 15.25 \\
\hline & & 2-Methylene-4-pentenal & 0.93 & & \\
\hline & & $\begin{array}{l}\text { Cycloheptanol, } \\
\text { 1-methyl-2-methylene- }\end{array}$ & 0.84 & & \\
\hline & & 4-(Ethylsulfanyl)-2-butanone & e 0.27 & & \\
\hline & & Alkynes (C5-C8) & 3.00 & & \\
\hline & & Alkanes (C19-C32) & 0.10 & & \\
\hline & & Benzene & 0.10 & & \\
\hline & & Others & 19.21 & & \\
\hline
\end{tabular}

\section{Conclusions}

The vinasse powder presented some of the most favorable physicochemical characteristics to be used as a raw material in a pyrolysis process. Its low ash content leads to a larger high heating value. In addition, the high content of volatile material and lignin favors the production of gaseous and liquid 
products during pyrolysis, as this biomass decomposes into additional organic components that lead to high liquid and gas yields.

All three biomass samples have a low concentration of sulfur and nitrogen and relatively high heating values; such characteristics are advantageous for pyrolysis processes. The pyrolysis at $450{ }^{\circ} \mathrm{C}$ (heating rate $7-8{ }^{\circ} \mathrm{C} / \mathrm{min}$ ) for $2 \mathrm{~h}$ favors the production of char $(42.7 \%-60.1 \%$ yield) for all biomass waste feedstock. The press mud showed the highest production of bio-char, but with a low content of carbon, while the powder vinasse produced a bio-char with almost $40 \%$ carbon content. The FTIR spectra of all bio-char evidenced the significant decomposition of organic components from all biomass samples; the presence of peaks characteristic to the $\mathrm{C}-\mathrm{O}$ group points to the capacity of further decomposition of organic compounds at a higher temperature. The results agreed with the TGA-DTG analysis, which showed that none of the biomass samples were completely decomposed at $450{ }^{\circ} \mathrm{C}$.

The pyrolysis of the extraction sludge exhibited the production of the highest amount of bio-oil and the lowest amount of gas, with bio-oil presenting aliphatic compounds (in particular with primary and secondary carbons), aromatics, and carbonyl compounds. The powder vinasse decomposition produced the lowest content of bio-char, along with pyrolysis bio-oil rich in aliphatic compounds, methoxy alcohols, and carbohydrates, as well as aromatic components. This biomass waste also exhibited the highest gas yield (owing to high volatiles content).

The extraction of sludge can be a good feedstock for the production of bio-oil and bio-char. All biomass samples show potential for pyrolysis; for bio-char production (press mud); for valuable chemicals like toluene, carboxylic acids, alkanes, and alkenes (press mud and extraction sludge); and for aliphatic, aromatic phenols, and ketones (powder vinasse).

Author Contributions: Conceptualization, N.M.C., C.E.A.-P., D.D.-V., and A.S.; Methodology, L.E.B.H., N.M.C., D.D.-V., C.E.A.-P., A.S., and E.G.; Software, J.S.D.-O.; Validation, C.E.A.-P., D.D.-V., A.S., and E.G.; Formal Analysis, J.S.D.-O., E.G., B.B., and A.S.; Investigation, J.S.D.-O., C.E.A.-P., D.D.-V., and A.S.; Resources, L.E.B.H., D.D.-V., E.G., and B.B.; Data Curation, J.S.D.-O., C.E.A.-P., and A.S.; Writing-Original Draft Preparation, J.S.D.-O., C.E.A.-P., D.D.-V., L.E.B.H., and A.S.; Writing-Review \& Editing, D.E., M.B., E.G., D.L., and A.S.; Visualization, J.S.D.-O. and A.S.; Supervision, C.E.A.-P., D.D.-V., N.M.C., and E.G.; Project Administration, S.G. and M.B.; Funding Acquisition, N.M.C., S.G., M.B., E.G., D.E., and M.S.

Funding: The current work is part of "ERANET-LAC" project under the Horizon 2020 programme. The authors (Devia-Orjuela, Alvarez-Pugliese, Donneys-Victoria, Barba Ho, and Marriaga Cabrales) gratefully acknowledge Colciencia (CT-482-2016 ELAC2015 T03-1018) and Universidad del Valle. The authors (E. Gal and A. Sauciuc) gratefully acknowledge the funding authorities: Romanian National Authority for Scientific Research and Innovation (CCCDI-UEFISCDI, 20/09.2019). Sebastiano Giardinelli and María Briceño gratefully acknowledge SENACYT Panama for financial support, under project ERANET/ELAC2015-T03-1018.

Acknowledgments: The authors (Devia-Orjuela, Alvarez-Pugliese, Donneys-Victoria, Barba Ho, and Marriaga Cabrales) gratefully acknowledge Colciencias, Universidad del Valle, Cenicaña and Leydi Johana Velasco.

Conflicts of Interest: The authors declare no conflict of interest.

\section{References}

1. USDA Sugar: World Markets and Trade. Available online: https://apps.fas.usda.gov/psdonline/circulars/ sugar.pdf (accessed on 5 June 2019).

2. Asocaña. Informe Anual: Aspectos Generales del Sector Agroindustrial de la Caña; Asocaña: Cali, Colombia, 2018.

3. Solomon, S. Sugarcane By-Products Based Industries in India. Sugar Tech 2011, 13, 408-416. [CrossRef]

4. Bhatnagar, A.; Kesari, K.K.; Shurpali, N. Multidisciplinary Approaches to Handling Wastes in Sugar Industries. Water Air Soil Pollut. 2016, 227, 11. [CrossRef]

5. Sarker, T.C.; Azam, S.M.G.G.; Bonanomi, G. Recent Advances in Sugarcane Industry Solid By-Products Valorization. Waste Biomass Valoriz. 2017, 8, 241-266. [CrossRef]

6. Quiroz, A.P.B.; Coca, A.L.B.; Baquero, P.P. Sostenibilidad del aprovechamiento del bagazo de caña de azùcar en el Valle del Cauca, Colombia. Ing. Solidar. 2017, 12, 133-149. [CrossRef]

7. Gupta, N.; Tripathi, S.; Balomajumder, C. Characterization of pressmud: A sugar industry waste. Fuel 2011, 90, 389-394. [CrossRef] 
8. Cortez, L.A.B.; Rossell, C.E.V.; Jordan, R.A.; Leal, M.R.L.V.; Lora, E.E.S. R\&D needs in the industrial production of vinasse. In Sugarcane Bioethanol-RED for Productivity and Sustainability; Cortez, L.A.B., Ed.; Editora Edgard Blücher: São Paulo, Brazil, 2014; pp. 619-636.

9. Zúñiga, V.; Gandini, M. Caracterización Ambiental De Las Vinazas De Residuos De Caña De Azúcar Resultantes De La Producción De Etanol. Dyna 2013, 80, 124-131.

10. Reis, C.E.R.; Hu, B. Vinasse from Sugarcane Ethanol Production: Better Treatment or Better Utilization? Front. Energy Res. 2017, 5, 1-7.

11. Christofoletti, C.A.; Escher, J.P.; Correia, J.E.; Marinho, J.F.U.; Fontanetti, C.S. Sugarcane vinasse: Environmental implications of its use. Waste Manag. 2013, 33, 2752-2761. [CrossRef]

12. Rabelo, S.C.; da Costa, A.C.; Rossel, C.E.V. Industrial Waste Recovery. In Sugarcane; Academic Press: Cambridge, MA, USA, 2015; pp. 365-381. [CrossRef]

13. Demirbas, A. Present and Future Transportation Fuels. Energy Sources Part A 2008, 30, 1473-1483. [CrossRef]

14. Yathavan, B. Conventional and Catalytic Pyrolysis of Pinyon Juniper Biomass. Master's Thesis, Utah State University, Logan, UT, USA, 2013; p. 2053.

15. Uddin, M.N.; Techato, K.; Taweekun, J.; Mofijur, M.; Rasul, M.G.; Mahlia, T.M.I.; Ashrafur, S.M. An Overview of Recent Developments in Biomass Pyrolysis Technologies. Energies 2018, 11, 3115. [CrossRef]

16. Papari, S.; Hawboldt, K. A review on the pyrolysis of woody biomass to bio-oil: Focus on kinetic models. Renew. Sustain. Energy Rev. 2015, 52, 1580-1595. [CrossRef]

17. Michailos, S.; Parker, D.; Webb, C. A techno-economic comparison of Fischer-Tropsch and fast pyrolysis as ways of utilizing sugar cane bagasse in transportation fuels production. Chem. Eng. Res. Des. 2017, 118, 206-214. [CrossRef]

18. Lin, B.-J.; Chen, W.-H. Sugarcane Bagasse Pyrolysis in a Carbon Dioxide Atmosphere with Conventional and Microwave-Assisted Heating. Front. Energy Res. 2015, 3, 4. [CrossRef]

19. Das, P.; Ganesh, A.; Wangikar, P. Influence of pretreatment for deashing of sugarcane bagasse on pyrolysis products. Biomass Bioenergy 2004, 27, 445-457. [CrossRef]

20. Inyang, M.; Gao, B.; Pullammanappallil, P.; Ding, W.; Zimmerman, A.R. Biochar from anaerobically digested sugarcane bagasse. Bioresour. Technol. 2010, 101, 8868-8872. [CrossRef]

21. Carrier, M.; Hardie, A.G.; Uras, Ü.; Görgens, J.; Knoetze, J. Production of char from vacuum pyrolysis of South-African sugar cane bagasse and its characterization as activated carbon and biochar. J. Anal. Appl. Pyrolysis 2012, 96, 24-32. [CrossRef]

22. Purnomo, C.W.; Salim, C.; Hinode, H. Preparation and characterization of activated carbon from bagasse fly ash. J. Anal. Appl. Pyrolysis 2011, 91, 257-262. [CrossRef]

23. Ansari, K.B.; Gaikar, V.G. Pressmud as an Alternate Resource for Hydrocarbons and Chemicals by Thermal Pyrolysis. Ind. Eng. Chem. Res. 2014, 53, 1878-1889. [CrossRef]

24. Dirbeba, M.J.; Brink, A.; DeMartini, N.; Zevenhoven, M.; Hupa, M. Potential for thermochemical conversion of biomass residues from the integrated sugar-ethanol process-Fate of ash and ash-forming elements. Bioresour. Technol. 2017, 234, 188-197. [CrossRef]

25. Dirbeba, M.J.; Aho, A.; DeMartini, N.; Brink, A.; Mattsson, I.; Hupa, L.; Hupa, M. Fast Pyrolysis of Dried Sugar Cane Vinasse at 400 and $500{ }^{\circ} \mathrm{C}$ : Product Distribution and Yield. Energy Fuels 2019, 33, 1236-1247. [CrossRef]

26. Da Silva, D.R.; Crespi, M.S.; Crnkovic, P.C.G.M.; Ribeiro, C.A. Pyrolysis, combustion and oxy-combustion studies of sugarcane industry wastes and its blends. J. Therm. Anal. Calorim. 2015, 121, 309-318. [CrossRef]

27. Basanta, R.; Delgado, M.A.G.; Martínez, J.E.C.; Vázquez, H.M.; Vázquez, G.B. Sostenibilidad Del Reciclaje De Residuos De La Agroindustria Azucarera: Una Revisión Sustainable Recycling of Waste From Sugarcane Agroindustry: A Review. CYTA J. Food 2007, 5, 293-305. [CrossRef]

28. Marrugo, G.; Valdés, C.F.; Chejne, F. Characterization of Colombian Agroindustrial Biomass Residues as Energy Resources. Energy Fuels 2016, 30, 8386-8398. [CrossRef]

29. Yadav, S.; Chandra, R. Biodegradation of organic compounds of molasses melanoidin (MM) from biomethanated distillery spent wash (BMDS) during the decolourisation by a potential bacterial consortium. Biodegradation 2012, 23, 609-620. [CrossRef]

30. Eliana, C.B.; Ho, L.E.B. Nilson Marriaga Tratamiento de Vinazas Acoplando: Extracción Con Alcohol, Electrodisolución-Floculación Y Blanqueamiento. Bachelor's Thesis, Universidad del Valle, Cali, Colombia, 2014. 
31. Biogreen Corporación S.A.S. Procedimiento Para la Producción de Fertilizante Orgaánico y El Producto Obtenido Mediante Dicho Procedimiento. Colombian Patent Application No. 15145641, 24 June 2015.

32. Frau, C.; Ferrara, F.; Orsini, A.; Pettinau, A. Characterization of several kinds of coal and biomass for pyrolysis and gasification. Fuel 2015, 152, 138-145. [CrossRef]

33. Saranraj, P.; Stella, D. Impact of sugar mill effluent to environment and bioremediation: A review. World Appl. Sci. J. 2014, 30, 299-316.

34. Lorenzetti, C.; Conti, R.; Fabbri, D.; Yanik, J. A comparative study on the catalytic effect of H-ZSM5 on upgrading of pyrolysis vapors derived from lignocellulosic and proteinaceous biomass. Fuel 2016, 166, 446-452. [CrossRef]

35. Neves, D.; Thunman, H.; Matos, A.; Tarelho, L.; Gómez-Barea, A. Characterization and prediction of biomass pyrolysis products. Prog. Energy Combust. Sci. 2011, 37, 611-630. [CrossRef]

36. Mamun, A.A.; Heim, H.P.; Bledzki, A.K. The use of maize, oat, barley and rye fibres as reinforcements in composites. In Biofiber Reinforcements in Composite Materials; Woodhead publishing: Sawston, UK, 2014; pp. 454-487. [CrossRef]

37. Naveen, C.; Premalatha, M. Thermo gravimetric and kinetic studies on dried solid waste of post-methanated distillery effluent under oxygen and nitrogen atmosphere. Bioresour. Technol. 2014, 174, 126-133. [CrossRef]

38. Agar, D.A.; Kwapinska, M.; Leahy, J.J. Pyrolysis of wastewater sludge and composted organic fines from municipal solid waste: Laboratory reactor characterisation and product distribution. Environ. Sci. Pollut. Res. 2018, 25, 35874-35882. [CrossRef]

39. Williams, P.T.; Besler, S. The influence of temperature and heating rate on the slow pyrolysis of biomass. Renew. Energy 1996, 7, 233-250. [CrossRef]

40. Al Arni, S. Comparison of slow and fast pyrolysis for converting biomass into fuel. Renew. Energy 2018, 124, 197-201. [CrossRef]

41. Parthasarathy, P.; Sheeba, K.N. Generation of fuel char through biomass slow pyrolysis. Energy Sources Part A Recover. Util. Environ. Eff. 2017, 39, 599-605. [CrossRef]

42. Ronsse, F.; van Hecke, S.; Dickinson, D.; Prins, W. Production and characterization of slow pyrolysis biochar: Influence of feedstock type and pyrolysis conditions. GCB Bioenergy 2013, 5, 104-115. [CrossRef]

43. Lee, Y.; Eum, P.-R.-B.; Ryu, C.; Park, Y.-K.; Jung, J.-H.; Hyun, S. Characteristics of biochar produced from slow pyrolysis of Geodae-Uksae 1. Bioresour. Technol. 2013, 130, 345-350. [CrossRef]

44. Palniandy, L.K.; Yoon, L.W.; Wong, W.Y.; Yong, S.-T.; Pang, M.M. Application of Biochar Derived from Different Types of Biomass and Treatment Methods as a Fuel Source for Direct Carbon Fuel Cells. Energies 2019, 12, 2477. [CrossRef]

45. Xu, F.; Yu, J.; Tesso, T.; Dowell, F.; Wang, D. Qualitative and quantitative analysis of lignocellulosic biomass using infrared techniques: A mini-review. Appl. Energy 2013, 104, 801-809. [CrossRef]

46. Popescu, C.-M.; Popescu, M.-C.; Vasile, C. Characterization of fungal degraded lime wood by FT-IR and 2D IR correlation spectroscopy. Microchem. J. 2010, 95, 377-387. [CrossRef]

47. Guizani, C.; Jeguirim, M.; Valin, S.; Limousy, L.; Salvador, S. Biomass Chars: The Effects of Pyrolysis Conditions on Their Morphology, Structure, Chemical Properties and Reactivity. Energies 2017, 10, 796. [CrossRef]

48. Gu, J.; Hu, W. Preparation Method of 2.2-Dimethoxypropane. Patent CN103772167A, 7 May 2014.

49. David, G.F.; Perez, V.H.; Justo, O.R.; Garcia-Perez, M. Effect of acid additives on sugarcane bagasse pyrolysis: Production of high yields of sugars. Bioresour. Technol. 2017, 223, 74-83. [CrossRef]

50. Khor, K.H.; Lim, K.O.; Zainal, Z.A. Characterization of Bio-Oil: A By-Product from Slow Pyrolysis of Oil Palm Empty Fruit Bunches. Am. J. Appl. Sci. 2009, 6, 1647-1652. [CrossRef]

51. Hsu, C.P.; Huang, A.N.; Kuo, H.P. Analysis of the rice husk pyrolysis products from a fluidized bed reactor. Procedia Eng. 2015, 102, 1183-1186. [CrossRef]

(C) 2019 by the authors. Licensee MDPI, Basel, Switzerland. This article is an open access article distributed under the terms and conditions of the Creative Commons Attribution (CC BY) license (http://creativecommons.org/licenses/by/4.0/). 